Original Article

\title{
Annual and seasonal changes of the air temperature with altitude in the Upper Dades valley, High Atlas, Morocco
}

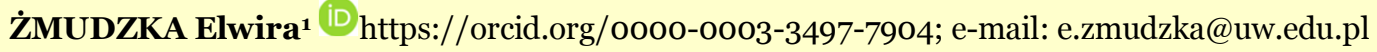 \\ DŁUŻEWSKI Maciej2* iD https://orcid.org/oooo-0002-2374-6863; $\$ e-mail: dluzewski@uw.edu.pl \\ DĄBSKI Maciej² iD https://orcid.org/oooo-0003-1018-9639; e-mail: mfdabski@uw.edu.pl \\ LEZIAK Kamil1 iD https://orcid.org/oooo-0oo3-0858-8163; e-mail: k.leziak@uw.edu.pl

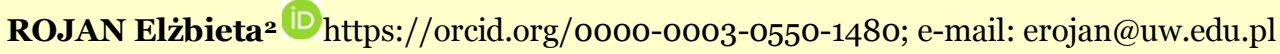 \\ * Corresponding author \\ 1 Department of Climatology, Faculty of Geography and Regional Studies, University of Warsaw, Krakowskie \\ Przedmieście 30, oo-927 Warsaw, Poland \\ 2 Department of Geomorphology, Faculty of Geography and Regional Studies, University of Warsaw, Krakowskie \\ Przedmieście 30, oo-927 Warsaw, Poland
}

Citation: Żmudzka E, Dłużewski M, Dąbski M, et al. (2022) Annual and seasonal changes of the air temperature with altitude in the Upper Dades valley, High Atlas, Morocco. Journal of Mountain Science 19(1). https://doi.org/10.1007/s11629-020-6662-6

(C) Author(s) 2022

\begin{abstract}
The purpose of this study is to determine the size of air temperature changes with altitude in the mountains of the arid zone, on the example of the Upper Dades valley (High Atlas, Morocco). The air temperature change with altitude was determined on the basis of 5 years data from three meteorological stations. The analysis was carried out on an annual and seasonal basis. The annual and daily variations of thermal gradients between pairs of stations were also determined. It was found that the average thermal gradient in the Upper Dades valley was $-1.02^{\circ} \mathrm{C}$ per $100 \mathrm{~m}$. The highest values of the thermal gradient occur in winter and the lowest in summer. In winter, the thermal gradient was characterized by the greatest variability. Minima of the daily variation of air temperature gradients were observed in early morning hours and maxima around midday. In the lower part of the valley, air temperature inversion frequently developed between $10 \mathrm{AM}$ and 3 PM UTC. The obtained results show high thermal gradients in
\end{abstract}

Received: 06-Jan-2021

1st Revision: 22-Jul-2021

$2^{\text {nd }}$ Revision: 25-Sep-2021

Accepted: 09-Oct-2021 the mountains of the arid zone, with their annual amplitude increasing in the lower parts of the valley. The instantaneous values of the gradients were significantly modified by the supply of latent heat and the occurrence of dust storms. It has been shown that the advection factor plays an important role in shaping large gradient values. The study contains novel results of thermal gradient measurements in high mountains of arid zone.

Keywords: Air temperature gradient; Thermal inversion; Annual and seasonal variability; Synoptic situation; High mountains of arid zone; High Atlas Mountains

\section{Introduction}

The variety of climatic conditions in mountain areas and the determination of the relationship between them and other components of the natural environment constitute an extensive stream of research in contemporary climatology. This is dictated 
by both cognitive and application considerations, e.g. the possibility of proper development of these areas and adaptation to the rapidly changing climate conditions. Determining changes in air temperature with altitude and learning about the mechanisms of their formation is important in modelling the temperature field in areas with varied relief (Rolland 2003; Blandford et al. 2008; Collados-Lara et al. 2021a,b), and the knowledge of thermal and precipitation gradients is widely used, e.g. in modelling glacier melting or runoff in high-lying catchments (Chutko and Lamoureux 2009; Petersen and Pellicciotti 2011; Ragettli et al. 2013; Immerzeel et al. 2014) as well as in modelling the transport path of pollutants and smog episodes in mountain valleys (Malek et al. 2006; Silcox et al. 2012; Rahman et al. 2015; Palarz and Celiński-Mysław 2017). The wide scope and complexity of this issue allows for its various approach.

One of the characteristics of the Earth's atmosphere is the change in air temperature with altitude. The mean value of the vertical gradient of air temperature (the environmental lapse rate) in the free atmosphere is $-0.65^{\circ} \mathrm{C}$ per $100 \mathrm{~m}$ (Barry and Chorley 2003; Blandford et al. 2005; Minder et al. 2010). This value is also often taken in studies of mountain atmosphere (e.g. Hann and Süring 1939; Liston et al. 1999). However, as numerous studies have shown (Yoshino 1984; Acevedo and Fitzjarrald 2001; Rolland 2003; Blandford et al. 2008; Dumas 2013; Gheyret et al. 2020; Rist et al. 2020) the value of the vertical air temperature gradient in terrain of diversified relief varies both spatially and in time. For example, Blandford et al. (2008) recommend different lapse rate values for different months (winter $T_{\max }$ between $-0.43^{\circ} \mathrm{C}$ and $-0.54^{\circ} \mathrm{C}$, summer $T_{\max }$ between $-0.68^{\circ} \mathrm{C}$ and $0.7^{\circ} \mathrm{C}$, winter $T_{\min }$ between $-0.12^{\circ} \mathrm{C}$ and $-0.33^{\circ} \mathrm{C}$ and summer $T_{\min }$ between $-0.19^{\circ} \mathrm{C}$ and $+0.03^{\circ} \mathrm{C}$ ). Provided data were obtained for Rocky Mountains in Idaho, but Blandford et al. (2008) argue that the general pattern should be similar elsewhere, which calls for further studies in different mountain ranges.

The main purpose of this study is to determine the size of air temperature changes with altitude in the high mountain valley of the arid climate, but under periodic influence of more humid air masses, and to compare the results with previously published works. We aim to characterise macroscale synoptic conditions in selected events of extreme temperature gradients. The basis of our work is the description of thermal and precipitation conditions, based on data from three meteorological stations located in the Upper Dades valley (High Atlas, Morocco) for the 5year period.

Permanent meteorological (synoptic) stations in Morocco, operated by the National Meteorological Direction (La Direction Générale de la Météorologie), are usually located in the coastal regions and only few in the mountains, therefore more detailed studies of air temperature patterns are rather limited to methods utilizing data from satellites (e.g. Hadria et al. 2018). Problems of several-year-long in-field measurement in the remote locations of Morocco constitute another major obstacle (we are not aware of similar research in High Atlas). Therefore, our study represents a novel and rare example of a smallscale study based on in-situ measurements performed in the Atlas mountains.

\section{Materials and Methods}

\subsection{Study site}

The Upper Dades catchment is located in the High Atlas (Morocco) (Fig. 1-A). This area $\left(1525 \mathrm{~km}^{2}\right)$ occupies the mountainous part of the catchment of the country's longest river system-Dades-Draa. This catchment area stretches from $1526 \mathrm{~m}$ a.s.l. (Boumalne town) up to $3313 \mathrm{~m}$ a.s.l. thus, the altitude difference is $1787 \mathrm{~m}$ (Rojan et al. 2020).

\subsubsection{Relief and geological setting}

The study area's geological setting, like most of the High Atlas, was formed during two phases of the formation of the entire massif system: the Late Eocene-Oligocene and the Upper Pliocene-Lower Quaternary. The relief consists of folded ridges of different ages, dislocated and uplifted at the beginning of the Tertiary, and then underwent numerous deformation and erosive cycles. The diversified resistance of the rocks led to the formation of both consistent and inversion relief. Jurassic carbonate sediments dominate among the rocks, mainly limestones, marls and dolomites. In the lower part of the studied area, there are Neogene conglomerates (Rojan et al. 2020).

The terrain relief of the Upper Dades catchment is characterized by wide plateaus at an altitude of over $3000 \mathrm{~m}$ a.s.l. They are bordered with slopes of usually low inclination (mainly $10^{\circ}-15^{\circ}$ ). The slope inclination 
A

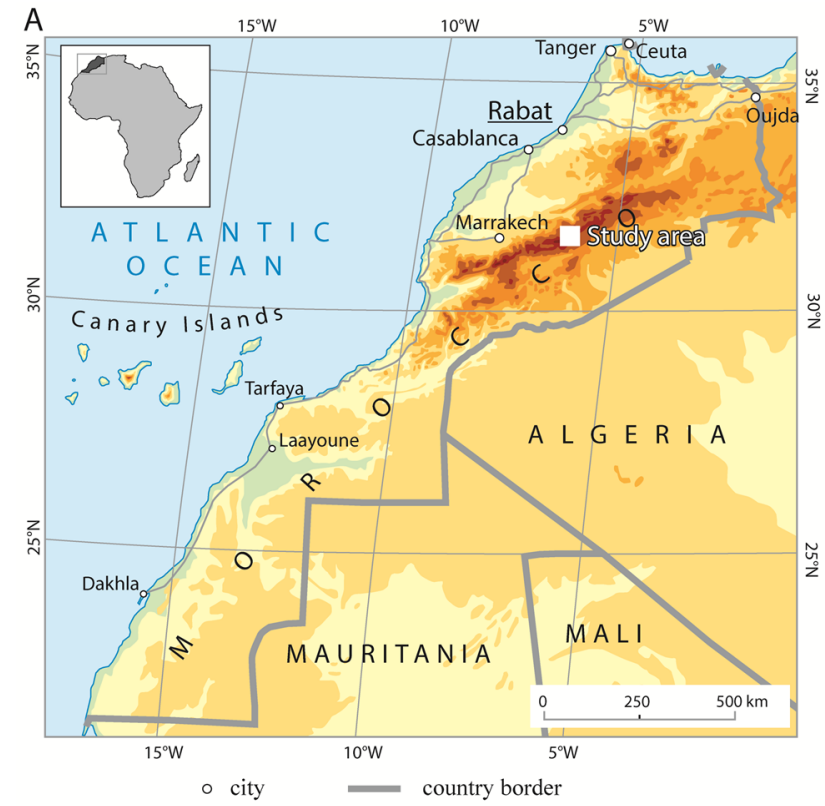

C

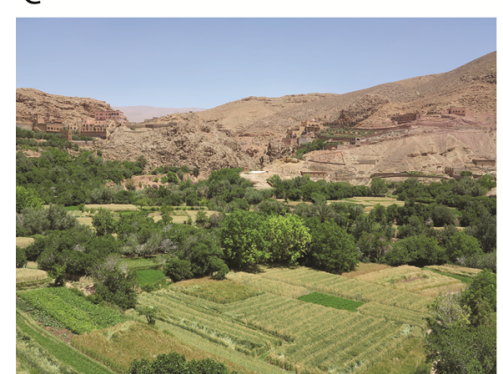

DAD1

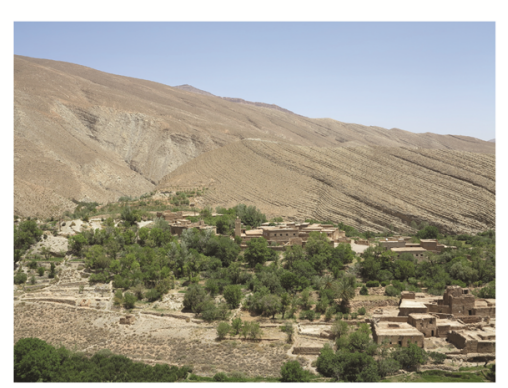

DAD2
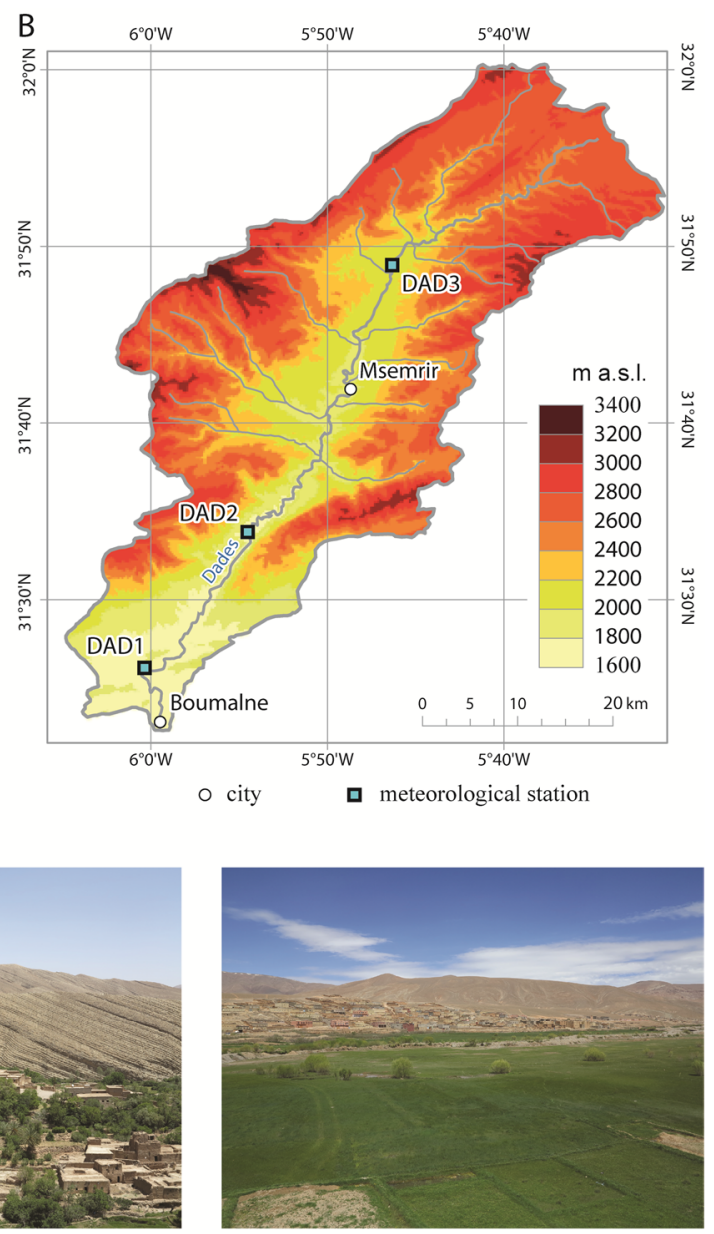

DAD3

Fig. 1 A - location of the study area in Morocco, B - Upper Dades catchment with the location of meteorological stations, $\mathrm{C}$ - surroundings of the meteorological stations.

usually increases with the distance from the peaks and it can be up to $90^{\circ}$. Geological structures significantly influence inclination of slopes and the longitudinal inclination of frequent river channels. The most important natural morphogenetic processes that transform the relief of the Upper Dades catchment area are the slope, fluvial and aeolian processes, which erode abundant weathering mantle. Almost all the episodic watercourse beds are well developed already at a distance of several dozen to several hundred meters from the plateau margins (Dłużewski et al. 2013). The alluvial fans deposited at mouths of the tributary river valleys are extensive and often force the relocation of the recipient river channel. The fluvial landforms are modelled by episodic high energy flood flows (Stokes and Mather 2015; Rojan et al. 2020).

\subsubsection{Climatic conditions}

The Upper Dades catchment has an arid mountain climate. Apart from high air temperature values depending on altitude, it is characterised by a significant variation in atmospheric precipitation. The average annual precipitation (1962-2006) at the Msemrir meteorological station (1942 m a.s.l.), located in the central part of the catchment, is 203 $\mathrm{mm}$ (Schultz et al. 2008), but in the lowest part of the study area (Boumalne, $1526 \mathrm{~m}$ a.s.l.), it does not exceed $150 \mathrm{~mm}$. Annual totals are highly changeable; the differences between the annual sums of precipitation can be as high as $400 \mathrm{~mm}$ (Schultz et al. 2008). In winter, snowfall occurs in the higher parts of the Upper Dades catchment. Between 2000 and $3000 \mathrm{~m}$ a.s.l. snow cover usually lasts up to 2 days, rarely up to several weeks. However, in the uppermost parts of the mountains the snow cover stays longer and its thickness can periodically reach up to several centimetres (Schultz and de Jong 2004). As much as $40 \%$ of the water accumulated in the snow cover in conditions of low air humidity and strong solar 
radiation is lost due to sublimation (on sunny winter days, humidity is only 20\%-30\%). Evaporation losses account for as much as $49 \%$ of the annual precipitation, the runoff for $28 \%$ and surface runoff for only $3 \%$ (de Jong et al. 2005).

Based on long-term meteorological data from Ifre - 1505 m a.s.l. (1963-1999) (Cappy 2006, Direction Regional Hydraulique, Agadir) and Msemrir - 1942 m a.s.l (1962-2006) (Regional Institute of Hydrology and Forestry in Tinechir, the Boumalne branch) four seasons can be distinguished in the southern part of High Atlas. Winter (December to February) is usually the coolest season and summer (June to August) - the hottest season, with average air temperature dependent on the altitude. Spring (March to May) and autumn (September to November) are characterised by similar air temperature. Contrary to seasonal air temperature variation, the highest precipitation occurs in autumn. Spring is the second season with high precipitation, whereas summer is the driest period. However, in the Upper Dades catchment the heavy rain can occur in the second half of August. Despite the lack of reliable data on cloud cover from in site meteorological stations, our more than 10 years of field observation showed that the cloud cover in this high mountain region varied greatly in time and in space, but generally cloudiness was much greater in spring and autumn, whereas in summer and winter sky was clear with only a few exceptions. In the southern part of the High Atlas dust storm occurs mostly in late spring and first half of the summer.

\subsubsection{Hydrography}

The main watercourse of the research area is $132 \mathrm{~km}$ long river Dades. In its highest part it is a periodic watercourse fed with meltwater and rainfall. Below, it receives water from several dozen of episodic tributaries, several times a year on average, mainly in the period September-October and February-April (Dłużewski et al. 2013). The runoff from the Upper Dades catchment area varies spatially and in time. It is mainly limited by rapid infiltration of rainwater and meltwater. In the upper-most part of the catchment, the runoff amounts to $3.5-4.5 \quad 1 . \mathrm{s}^{-1} \cdot \mathrm{km}^{-2} \quad(0.0035-0.0045$ $\mathrm{m}^{3} \cdot \mathrm{s}^{-1} \cdot \mathrm{km}^{-2}$ ) (Fink and Knippertz 2003). The average annual flow in the Aït Moutad hydrometric profile (above Boumalne) is $33 \mathrm{~m}^{3} \cdot \mathrm{s}^{-1}$, which gives the value of unit runoff (from an area of $1525 \mathrm{~km}^{2}$ ) equal to $0.0218 \mathrm{~m}^{3} \cdot \mathrm{s}^{-1} \cdot \mathrm{km}^{-2}$. During the periodic lack of rainfall, the riverbed is fed with karst underground waters.

\subsubsection{Vegetation}

Vegetation of the Upper Dades catchment is relatively poor. The slopes are dominated by slightly dense shrubs consisting mainly of Lamiaceae, Asteraceae and Fabaceae families, and single specimens of juniper (Juniperus ssp.) from the cypress family (Cupressaceae). Vegetation is subjected to very strong pressure and shows signs of intense browsing. The floor of the valley is dominated by crops (vegetables, potatoes, cereals and meadows), spontaneous and cultivated woody vegetation (e.g. poplars, apple trees, almond trees) and shrubs (oleanders), as well as spontaneous hygrophilous vegetation associated with the river and ruderal vegetation.

\subsection{Methods}

The study is based on data from three meteorological stations (Table 1, Fig. 1) established in 2012 in the Upper Dades valley. The difference in altitude between the lowest and highest station is almost $450 \mathrm{~m}$. The 5-year period (from July $1^{\text {st }}, 2012$ to Jun $30^{\text {th }}, 2017$ ) was used in the research.

The meteorological stations were located at mouths of three episodic tributary rivers which drain to the main Dades valley (Fig. 1-A). Each station was installed on the roof of a 2-story building (approximately $6 \mathrm{~m}$ high), on a $2 \mathrm{~m}$ high mast. The buildings were surrounded by green areas used as cultivated fields, woods, scrubs or hygrophilous vegetation (Fig. 1-B).

Air temperature was measured by the Onset Computer Corporation sensors with a resolution of $0.1^{\circ} \mathrm{C}$ and an accuracy of $\pm 0.47^{\circ} \mathrm{C}$ at an air temperature of $25^{\circ} \mathrm{C}$. The temperature sensors were protected by solar radiation shields. The data was

Table 1 Location of meteorological stations used in the research.

\begin{tabular}{|c|c|c|c|c|}
\hline \multirow{2}{*}{ Stations } & \multirow{2}{*}{ Village } & \multicolumn{2}{|l|}{ Coordinates } & \multirow{2}{*}{$\begin{array}{l}\text { Altitude } \\
\text { (m a.s.l.) }\end{array}$} \\
\hline & & Latitude & Longitude & \\
\hline DAD1 & Ait Ibriren & $31^{\circ} 26^{\prime} 13^{\prime \prime} \mathrm{N}$ & $6^{\circ} 00^{\prime} 44^{\prime \prime} \mathrm{W}$ & 1618 \\
\hline DAD2 & Ait Hammou & $31^{\circ} 34^{\prime} 10^{\prime \prime} \mathrm{N}$ & $5^{\circ} 54^{\prime} 20^{\prime \prime} \mathrm{W}$ & 1750 \\
\hline DAD3 & Ait Attou & $31^{\circ} 48^{\prime} 50^{\prime \prime} \mathrm{N}$ & $5^{\circ} 46^{\prime} 10^{\prime \prime} \mathrm{W}$ & 2064 \\
\hline
\end{tabular}


recorded in the $\mathrm{HOBO} \AA$ data logger at 30-minute intervals. Precipitation was measured by the Onset Computer Corporation's Rain Gauge Smart Sensor with a resolution of $0.2 \mathrm{~mm}$ and an accuracy of $\pm 4.0 \%$ and recorded in the $\mathrm{HOBO} ß$ data logger. The upper station was additionally equipped with an electric heater that turns on when the air temperature falls below $0^{\circ} \mathrm{C}$, enabling conversion of solid precipitation into water.

The vertical air temperature gradient is most often calculated using the difference quotient method (pair of stations) or the least squares method (regression coefficient connecting air temperature with altitude). It is usually assumed that under conditions of good atmospheric mixing, air temperature increases or decreases linearly with altitude (Lundquist et al. 2008; Marshall and Sharp 2009). However, micro-scale measurements in mountain regions can contradict this assumption, because of the influence of local flow of air masses (Collados-Lara et al. 2021a).

The method based of the pairs of stations, which allows to obtain the gradient values quickly and easily, is strongly dependent on the selection of station pairs used in the calculations. Hann and Süring (1939) found that it generally gives overestimated results, which is probably due to the fact that calculations are based on measurements from points located in deeply incised valleys and on isolated mountain peaks. A similar view was presented by Alisov et al. (1952), arguing that this method should be used in calculations for pairs of similarly located stations. Therefore, in this research all measurement stations were located on the valley floor, in similar morphological situations.

The calculations of instantaneous values of the air temperature gradient were made between pairs of stations: DAD1 and DAD2, DAD2 and DAD3 as well as DAD1 and DAD3. The air temperature gradient was calculated according to the formula:

$$
L R=\frac{T 1-T 2}{z 1-z 2}=\frac{d T}{d z}
$$

where, $T_{1}$ and $T_{2}$ - air temperature values $\left({ }^{\circ} \mathrm{C}\right)$ measured on selected stations, $z 1$ and $z 2$ - altitude of the stations (in $\mathrm{m}$ a.s.l.). The gradient is expressed in ${ }^{\circ} \mathrm{C}$ per $100 \mathrm{~m}$. Its negative values mean the decrease of air temperature with elevation, and positive values - increase of air temperature with elevation i.e. thermal inversion (e.g. Blandford et al. 2008; Kattel et al. 2013, 2018).
Mean daily air temperature gradients were calculated as the mean of 48 terms. There were a few gaps in the data (0.2\% for instantaneous data and $0.12 \%$ for daily data). Median, interquartile range and extreme values of the instantaneous and daily air temperature gradient values were determined. Moreover, the following coefficients were calculated: variation $\mathrm{V}$, skewness $\mathrm{A}$ and flattening $\mathrm{Ku}$. The analysis was carried out on an annual and seasonal basis.

The annual variability of the thermal gradient was determined based of aggregated values to monthly values. Events of extremely low (below the $5^{\text {th }}$ percentile) and extremely high (above the $95^{\text {th }}$ percentile) gradients were identified. In relation to these situations, the synoptic conditions were analysed.

In order to visualize the movement of air particles, retrograde trajectories determined from the HYSPLIT model were used (Stein et al. 2015) with a time horizon of 96 hours and a six-hour interval (model available at http://www.arl.noaa.gov/ ready.html). A standard model of air particle motion was used. Retrograde trajectories were determined in relation to the air becoming stagnant at three levels: near the earth's surface (500 $\mathrm{m}$ above ground surface), at the upper boundary layer border $(1500 \mathrm{~m})$ and in the free troposphere $(3000 \mathrm{~m})$ using meteorological data from the GFSG model. The retrograde trajectories were calculated with reference to the point with the coordinates $31^{\circ} 26^{\prime} 13^{\prime \prime} \mathrm{N}, 6^{\circ} 00^{\prime} 44^{\prime \prime} \mathrm{W}$, which corresponds to the lowest station.

The HYSPLIT model, applied in our study, has been utilized and improved for several decades and is currently one of the most commonly used complete systems for calculating air mass trajectories, as well as complex simulations of transport, dispersion, chemical transformation and deposition of atmospheric pollutants (Draxler and Taylor 1982). A common application of the model is the analysis of trajectory to reconstruct the origin of air masses and determination of the source-receptor relationship (Formenti et al. 2001; Escudero et al. 2010; Alam et al. 2011). This method is also widely used in mountain areas (Bacardit and Camarero 2009; Fiorella 2015).

\section{Results}

\subsection{Air temperature and precipitation conditions}

The average annual air temperature in the 
studied valley in the period 2013-2017 ranged from $12.5^{\circ} \mathrm{C}$ at the $\mathrm{DAD} 3$ station to $17.5^{\circ} \mathrm{C}$ at the $\mathrm{DAD} 1$ station (Table 2). A significant decrease in the mean minimum air temperature with altitude was observed $\left(\mathrm{DAD} 1-11.7^{\circ} \mathrm{C}, \mathrm{DAD} 2-10.3^{\circ} \mathrm{C}, \mathrm{DAD} 3-4.7^{\circ} \mathrm{C}\right.$ ), with a relatively small difference in the mean maximum temperature (DAD1 $-22.9^{\circ} \mathrm{C}, \mathrm{DAD} 2-23.0^{\circ} \mathrm{C}, \mathrm{DAD} 3$ $-20.7^{\circ} \mathrm{C}$. The warmest month was July, and the coldest was December (Fig. 2-A).

As the altitude increased, the range of air temperature values also increased - the highest station experienced the lowest $\left(-10.1^{\circ} \mathrm{C}\right)$ and the highest $\left(40.4^{\circ} \mathrm{C}\right)$ instantaneous temperature ever recorder throughout the research period (Table 3).

In terms of atmospheric precipitation, the analysed period did not differ significantly from the long-term periods (Table 2). Despite the increase in mean annual precipitation with altitude, the annual precipitation abundance, defined as the ratio of annual precipitation to number of days with precipitation $\geq 1 \mathrm{~mm}$, was lower at the highest station
DAD3 (5.2 $\mathrm{mm}$ per day) than at the lower station DAD2 (6.3 $\mathrm{mm}$ per day). This was due to lower numbers of days with precipitation in station DAD2. The lowest number of such days occurred at the lowest station (25.4 days during the year), and the highest at the highest station (35.0 days).

Precipitation sums and the number of days with precipitation show a specific pattern in the annual course. At all stations, the lowest mean number of days with precipitation during the year occurred in December (from 0.4 to 1.3 of a day in DAD1 and DAD3, respectively), and the highest in August (from 3.6 to 6.8 of a day in DAD1 and DAD3, respectively). At the stations located lower (DAD1 and DAD2), the most days with precipitation (more than three per month) occurred from August to October, at the highest station (DAD3) from July to November and March, with most significant maximum in August. As a result, in summer there were the same number of days with precipitation as in autumn (both seasons had 11 days).

Table 2 Annual and seasonal average of air temperature values and the sum of precipitation in the Upper Dades valley.

\begin{tabular}{|l|l|l|l|l|l|l|}
\hline \multirow{2}{*}{ Months } & \multicolumn{3}{|c|}{ Air temperature $\left({ }^{\circ} \mathrm{C}\right)$} & \multicolumn{3}{c|}{ Atmospheric precipitation (mm) } \\
\hline Dec. - Feb. & DAD1 & DAD2 & DAD3 & DAD1 & DAD2 & DAD3 \\
\hline Mar. - May & 8.5 & 8.0 & 4.4 & 16.7 & 19.5 & 16.3 \\
\hline Jun. - Aug. & 17.2 & 16.5 & 12.7 & 19.8 & 20.0 & 27.7 \\
\hline Sept. - Nov. & 26.5 & 25.4 & 21.2 & 14.9 & 21.7 & 19.9 \\
\hline Jan. - Dec. & 17.5 & 16.7 & 13.0 & 51.1 & 41.7 & 38.5 \\
\hline
\end{tabular}
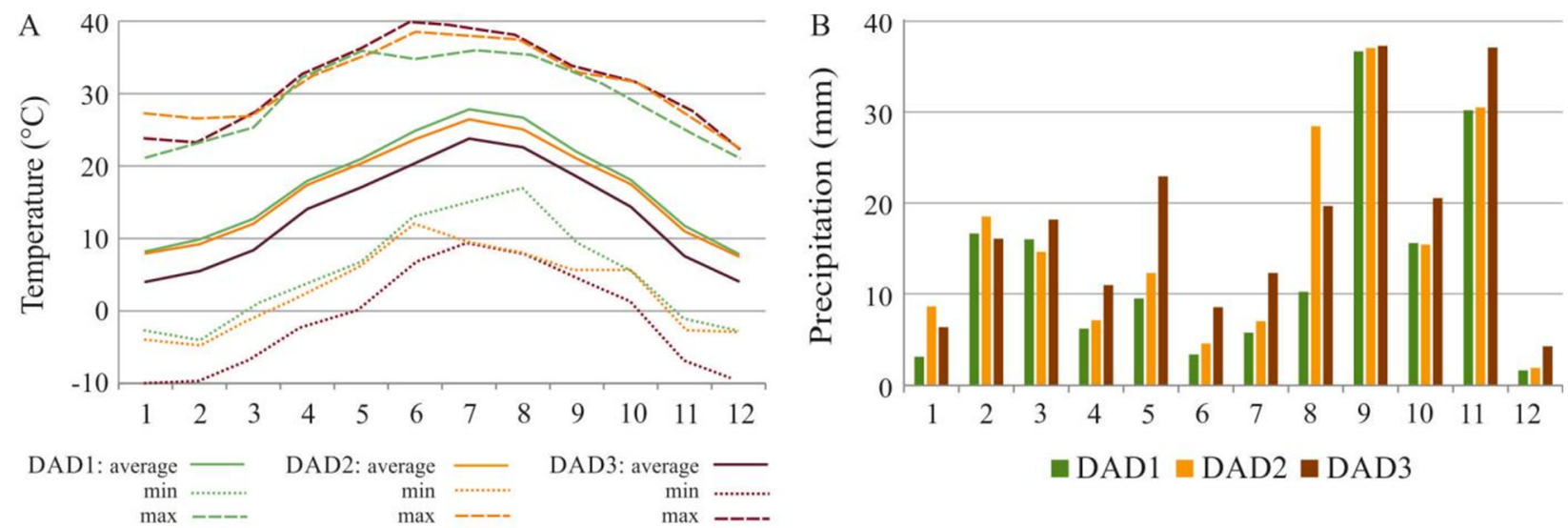

Fig. 2 Monthly average, minimum and maximum air temperature (A) and monthly average total precipitation (B) at the stations DAD1, DAD2, DAD3 in the Upper Dades valley.

Table 3 Extreme values of air temperature with the dates of their occurrence in the Upper Dades valley.

\begin{tabular}{|l|l|l|l|l|}
$\begin{array}{l}\text { Meteorological } \\
\text { station }\end{array}$ & $\begin{array}{l}\text { Lowest temperature } \\
\text { value }\left({ }^{\circ} \mathrm{C}\right)\end{array}$ & $\begin{array}{l}\text { Date of lowest } \\
\text { temperature }\end{array}$ & $\begin{array}{l}\text { Highest temperature } \\
\text { value }\left({ }^{\circ} \mathrm{C}\right)\end{array}$ & $\begin{array}{l}\text { Date of highest } \\
\text { temperature }\end{array}$ \\
\hline $\mathrm{DAD} 1$ & -4.0 & 16.02 .2016 & 36.5 & 28.07 .2017 \\
\hline $\mathrm{DAD} 2$ & -4.6 & 17.02 .2016 & 39.2 & 25.06 .2013 \\
\hline $\mathrm{DAD} 3$ & -10.1 & 25.01 .2017 & 40.4 & 25.06 .2013 \\
\hline
\end{tabular}


The annual variation of precipitation was complex: the highest sums occurred in September and November, and in the case of DAD2 and DAD3 also in August (Fig. 2-B). The secondary maximum occurred in February and March, and a slight increase also took place in May. The lowest sums were recorded in December. January, April, June and July were also dry (average precipitation was less than $10 \mathrm{~mm}$ ). At the lowest station (DAD1) the lowest precipitation occurred in summer $(14.9 \%$ of the annual total), in the middle and upper parts of the valley (DAD2 and DAD3), the lowest precipitation was recorded in winter (19.5\% and $16.3 \%$ of the annual total, respectively). At all stations, the greatest sum of precipitation was recorded in autumn; they accounted for from $38.5 \%$ of the annual total in $\mathrm{DAD}_{3}$ to $51.1 \%$ in DAD1 (from September to November all stations recorded highest precipitation in the analysed period).

In August the highest precipitation was recorded at an altitude of $1750 \mathrm{~m}$ a.s.l. (DAD2). The sums were over three times greater than that at the DAD1 station, located at $132 \mathrm{~m}$ lower elevation. The average precipitation abundance was also the highest $(6.6 \mathrm{~mm}$ per day with precipitation). A similar situation occurred in January, but the average precipitation sum in the five-year period was small in this month. It was a consequence of only 5 days with precipitation (average abundance was $8.6 \mathrm{~mm}$ per day with precipitation). At the highest station (DAD3), the highest precipitation was in spring (April, May), and in the lower part of the valley (DAD2, DAD1) in November.

The highest daily sum of precipitation at the DAD1 station $(57.2 \mathrm{~mm})$ occurred on September 21, 2014 (it was the only case in the analysed period with a daily sum exceeding $50 \mathrm{~mm}$ ). Precipitation on that day was also the highest at the stations DAD3 36.2 $\mathrm{mm}$ ) and DAD2 (42.4 $\mathrm{mm}$ ), however here, the greater sum of precipitation occurred on August 16, 2015 $(44.4 \mathrm{~mm})$. In the remaining cases, the highest precipitation occurred only at one station. At individual stations, there were from 2 (DAD3) to 4 (DAD1 and DAD2) days with the daily totals exceeding $30 \mathrm{~mm}$ and from 17 (DAD1) to 22 (DAD3) days with the daily total exceeding $10 \mathrm{~mm}$.

\subsection{Air temperature changes with altitude}

The mean air temperature gradient in the Upper
Dades valley was $-1.02^{\circ} \mathrm{C}$ per $100 \mathrm{~m}$ (DAD1-DAD3). In the lower part of the valley (DAD1-DAD2) it was close to the average gradient in the atmosphere and amounted to $-0.59^{\circ} \mathrm{C}$, and in the upper part (DAD2$\mathrm{DAD} 3$ ) it was more than twice as high $-1.22^{\circ} \mathrm{C}$ per 100 $\mathrm{m}$. During the year, the lowest gradient values, independently per pair of stations, occurred in winter, and the largest in summer (Table 4).

Table 4 Annual and seasonal average of air temperature gradients $\left({ }^{\circ} \mathrm{C}\right.$ per $\left.100 \mathrm{~m}\right)$ between individual pairs of stations in the Upper Dades valley.

\begin{tabular}{|c|c|c|c|}
\hline Months & $\begin{array}{l}\text { DAD1- } \\
\text { DAD2 }\end{array}$ & $\begin{array}{l}\text { DAD1- } \\
\text { DAD3 }\end{array}$ & $\begin{array}{l}\text { DAD2- } \\
\text { DAD3 }\end{array}$ \\
\hline Dec. - Feb. & -0.34 & -0.92 & -1.16 \\
\hline Mar. - May & -0.55 & -1.00 & -1.20 \\
\hline Jun. - Aug. & -0.84 & -1.17 & -1.33 \\
\hline Sept. - Nov. & -0.65 & -1.02 & -1.18 \\
\hline Jan. - Dec. & -0.59 & -1.02 & -1.22 \\
\hline
\end{tabular}

The variation of the air temperature gradient in the analysed 5-year period was the largest in the lower part of the valley (DAD1-DAD2) (Fig. 3): the standard deviation was $106 \%$ (daily) and $223 \%$ (instantaneous) of the average gradient value, respectively (Table 5). The interquartile range of instantaneous gradient for this pair of stations was $1.46^{\circ} \mathrm{C}$ per $100 \mathrm{~m}$, and the $3^{\text {rd }}$ quartile was positive (Fig. 3-B). The air temperature gradient in the upper part of the valley (DAD2-DAD3) was less variable (Fig 3, Table 5). The distribution of the gradient values across the valley, with the exception of the instantaneous values between DAD2 and DAD3, was characterized by positive asymmetry.

The air temperature gradient in the studied valley (irrespective of the pair of stations) was characterized by the greatest variability in winter and the smallest in summer (Table 6, Fig. 4). A positive value of the $3^{\text {rd }}$ quartile of the air temperature gradient (air temperature inversion) was found only in the lower part of the valley (DAD1-DAD2) in the case of daily values in winter (Fig. 4-A) and in the case of instantaneous values in winter and spring (Fig. 4-B). In other cases, it had a negative value.

The extreme values of the air temperature gradient changed from season to season (Table 7). During the year, the extremely low values of the mean daily and instantaneous air temperature gradients $\left(1^{\text {st }}\right.$ and $5^{\text {th }}$ percentiles) in the lower part of the valley (DAD1-DAD2) and in the entire valley (DAD1-DAD3) were recorded in summer, whereas in the upper part of the valley (DAD2-DAD3) - also in winter. 

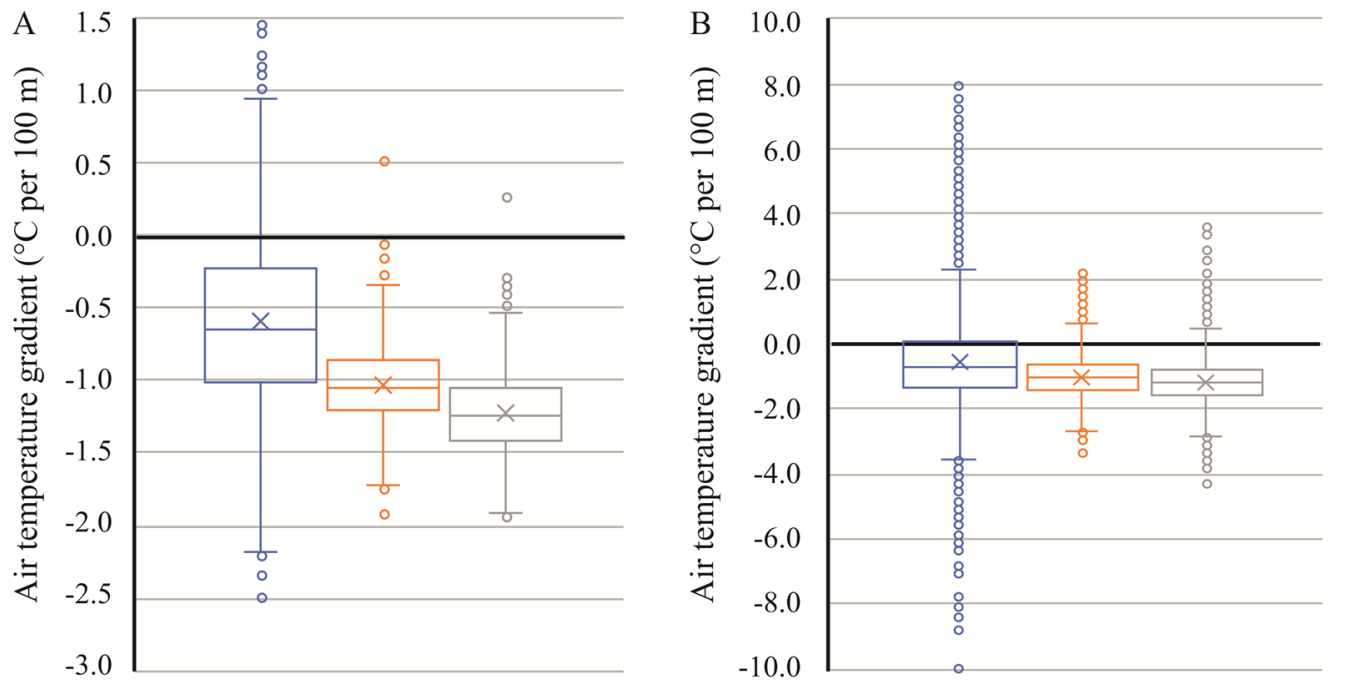

$\square$ DAD1-DAD2

DAD1-DAD3

DAD2-DAD3

$\therefore \quad$ outliers

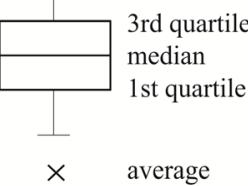

Fig. 3 Annual distribution of daily (A) and instantaneous (B) values of the air temperature gradient $\left({ }^{\circ} \mathrm{C}\right.$ per $\left.100 \mathrm{~m}\right)$ between pairs of stations in the Upper Dades valley.

Table 5 Annual average values of the coefficients: $\mathrm{V}$ - variation, $\mathrm{A}$ - skewness and $\mathrm{Ku}$ - kurtosis as well as selected percentiles of daily and instantaneous air temperature gradients between pairs of stations in the Upper Dades valley.

\begin{tabular}{|c|c|c|c|c|c|c|c|}
\hline \multirow{2}{*}{\multicolumn{2}{|c|}{$\begin{array}{l}\text { Pairs of stations } \\
\text { Coefficient }\end{array}$}} & \multicolumn{3}{|c|}{ Daily gradients $\left({ }^{\circ} \mathrm{C}\right)$} & \multicolumn{3}{|c|}{ Instantaneous gradients $\left({ }^{\circ} \mathrm{C}\right)$} \\
\hline & & DAD1-DAD2 & DAD1-DAD3 & DAD2-DAD3 & DAD1-DAD2 & DAD1-DAD3 & DAD2-DAD3 \\
\hline \multicolumn{2}{|l|}{ V } & 1.06 & 0.26 & 0.22 & 2.23 & 0.60 & 0.54 \\
\hline \multicolumn{2}{|l|}{ A } & 0.27 & 0.41 & 0.48 & 0.61 & 0.54 & -0.09 \\
\hline \multicolumn{2}{|l|}{$\mathrm{Ku}$} & 0.09 & 0.54 & 0.63 & 2.92 & 0.79 & 0.69 \\
\hline \multirow{4}{*}{ Percentiles } & 1 & -1.89 & -1.60 & -1.80 & -3.40 & -2.26 & -2.83 \\
\hline & 5 & -1.53 & -1.42 & -1.62 & -2.37 & -1.92 & -2.35 \\
\hline & 95 & 0.55 & -0.55 & -0.73 & 1.68 & 0.04 & -0.22 \\
\hline & 99 & 0.98 & -0.34 & -0.50 & 2.52 & 0.75 & 0.36 \\
\hline
\end{tabular}

Table 6 Seasonal average values of the coefficients: V - variation, A - skewness and Ku - kurtosis of daily and instantaneous air temperature gradients between pairs of stations in the Upper Dades valley.

\begin{tabular}{|c|c|c|c|c|c|}
\hline \multirow{2}{*}{ Coefficient } & \multirow{2}{*}{ Pairs of stations } & \multicolumn{4}{|c|}{ Daily gradients $\left({ }^{\circ} \mathrm{C}\right)$} \\
\hline & & Dec. - Feb. & Mar. - May & Jun. - Aug & Sept. - Nov. \\
\hline \multirow{3}{*}{$\mathrm{V}$} & DAD1-DAD2 & 1.99 & 1.11 & 0.66 & 0.80 \\
\hline & DAD1-DAD3 & 0.30 & 0.26 & 0.19 & 0.25 \\
\hline & DAD2-DAD3 & 0.26 & 0.21 & 0.15 & 0.24 \\
\hline \multirow{3}{*}{ A } & DAD1-DAD2 & -0.13 & 0.19 & 0.43 & 0.40 \\
\hline & DAD1-DAD3 & 0.25 & 0.41 & 0.67 & 0.22 \\
\hline & DAD2-DAD3 & 0.28 & 0.35 & 0.45 & 0.41 \\
\hline \multirow{3}{*}{$\mathrm{Ku}$} & DAD1-DAD2 & -0.08 & 0.01 & 1.20 & 0.20 \\
\hline & DAD1-DAD3 & 1.62 & 0.01 & 0.84 & 0.34 \\
\hline & DAD2-DAD3 & 0.73 & 0.25 & 1.31 & 0.02 \\
\hline \multirow{2}{*}{ Coefficient } & & \multicolumn{4}{|c|}{ Instantaneous gradients $\left({ }^{\circ} \mathrm{C}\right)$} \\
\hline & Pairs of stations & Dec. - Feb. & Mar. - May & Jun. - Aug & Sept. - Nov. \\
\hline \multirow{3}{*}{ V } & DAD1-DAD2 & 3.82 & 2.73 & 1.55 & 1.80 \\
\hline & DAD1-DAD3 & 0.64 & 0.64 & 0.53 & 0.57 \\
\hline & DAD2-DAD3 & 0.59 & 0.52 & 0.48 & 0.54 \\
\hline \multirow{3}{*}{ A } & DAD1-DAD2 & 0.40 & 1.18 & 0.95 & 0.53 \\
\hline & DAD1-DAD3 & 0.59 & 0.75 & 0.52 & 0.39 \\
\hline & DAD2-DAD3 & -0.13 & -0.04 & -0.13 & -0.07 \\
\hline \multirow{3}{*}{$\mathrm{Ku}$} & DAD1-DAD2 & 0.94 & 2.54 & 4.88 & 2.54 \\
\hline & DAD1-DAD3 & 0.44 & 1.12 & 0.99 & 0.48 \\
\hline & DAD2-DAD3 & 0.62 & 0.74 & 0.73 & 0.69 \\
\hline
\end{tabular}


Extremely high mean daily air temperature gradients (95 ${ }^{\text {th }}$ and $99^{\text {th }}$ percentiles), positive (air temperature inversion) in the lower part of the valley (DAD1-DAD2) in all seasons, were recorded in winter. In the upper part of the valley (DAD2-DAD3) and in the whole valley (DAD1-DAD3), they were negative throughout the year, and the greatest decrease in air temperature with height was found in summer. Extremely high instantaneous air temperature gradient values $\left(99^{\text {th }}\right.$ percentile) were positive (air temperature inversion) regardless of the season and a pair of stations. The highest absolute values in the lower part of the valley and in the entire valley were found in spring, and in the upper part in winter. There was a similar pattern for the $95^{\text {th }}$ percentile at the bottom of the valley, with the seasonal gradient values being negative at the top of the valley, and the highest value occurring in summer. Across the valley, the $95^{\text {th }}$ percentile was negative in summer and autumn, positive in winter and spring, and the highest absolute value was in summer.

The values of the air temperature gradient aggregated to months were quite even throughout the year (Fig. 5-A). The annual variation of these values within whole valley (DAD1-DAD3) was characterized by a poorly marked minimum in August $\left(-1.26^{\circ} \mathrm{C}\right.$ per $100 \mathrm{~m})$ and July $\left(-1.23^{\circ} \mathrm{C}\right.$ per $\left.100 \mathrm{~m}\right)$, and a maximum in December $\left(-0.83^{\circ} \mathrm{C}\right.$ per $\left.100 \mathrm{~m}\right)$. Between $1750 \mathrm{~m}$ a.s.l. and $2064 \mathrm{~m}$ a.s.l. (DAD2-DAD3) the gradient values were lower than $-1.0^{\circ} \mathrm{C}$ throughout the year.
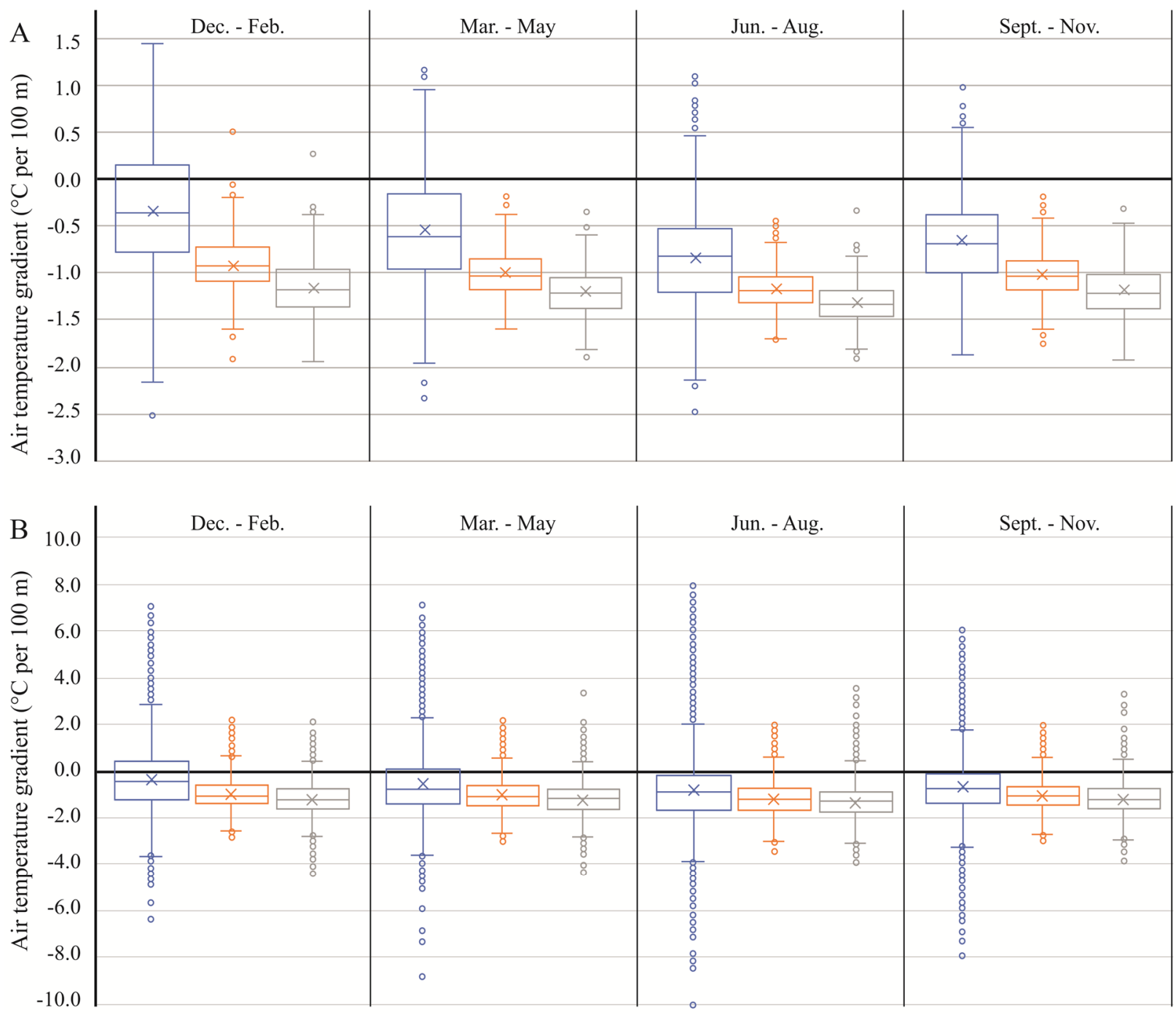

$\square$ DAD1-DAD2 $\square$ DAD1-DAD3 $\square$ DAD2-DAD3

Fig. 4 Seasonal distribution of daily (A) and instantaneous (B) values of the air temperature gradient $\left({ }^{\circ} \mathrm{C}\right.$ per $\left.100 \mathrm{~m}\right)$ between pairs of stations in the Upper Dades valley, explanation of boxplot as in Fig. 3 . 
Table 7 Seasonal average extreme values (percentiles) of daily and instantaneous air temperature gradients between pairs of stations in the Upper Dades valley.

\begin{tabular}{|c|c|c|c|c|c|}
\hline \multirow{2}{*}{ Percentile } & \multirow{2}{*}{ Pairs of stations } & \multicolumn{4}{|c|}{ Daily gradients $\left({ }^{\circ} \mathrm{C}\right)$} \\
\hline & & Dec. - Feb. & Mar. - May & Jun. - Aug & Sept. - Nov. \\
\hline \multirow{3}{*}{1} & DAD1-DAD2 & -1.88 & -1.87 & -2.15 & -1.76 \\
\hline & DAD1-DAD3 & -1.60 & -1.54 & -1.63 & -1.58 \\
\hline & DAD2-DAD3 & -1.83 & -1.72 & -1.83 & -1.74 \\
\hline \multirow{3}{*}{5} & DAD1-DAD2 & -1.47 & -1.56 & -1.65 & -1.45 \\
\hline & DAD1-DAD3 & -1.32 & -1.40 & -1.49 & -1.41 \\
\hline & DAD2-DAD3 & -1.66 & -1.58 & -1.62 & -1.59 \\
\hline \multirow{3}{*}{95} & DAD1-DAD2 & 0.73 & 0.57 & 0.16 & 0.32 \\
\hline & DAD1-DAD3 & -0.50 & -0.53 & -0.78 & -0.58 \\
\hline & DAD2-DAD3 & -0.67 & -0.75 & -0.98 & -0.63 \\
\hline \multirow{3}{*}{99} & DAD1-DAD2 & 1.12 & 0.92 & 0.77 & 0.73 \\
\hline & DAD1-DAD3 & -0.28 & -0.31 & -0.51 & -0.35 \\
\hline & DAD2-DAD3 & -0.39 & -0.59 & -0.79 & -0.49 \\
\hline \multirow{2}{*}{ Percentile } & \multirow{2}{*}{ Pairs of stations } & \multicolumn{4}{|c|}{ Instantaneous gradients $\left({ }^{\circ} \mathrm{C}\right)$} \\
\hline & & Dec. - Feb. & Mar. - May & Jun. - Aug & Sept. - Nov. \\
\hline \multirow{3}{*}{1} & DAD1-DAD2 & -2.99 & -3.00 & -3.41 & -3.27 \\
\hline & DAD1-DAD3 & -2.05 & -2.19 & -2.41 & -2.21 \\
\hline & DAD2-DAD3 & -2.89 & -2.74 & -2.86 & -2.74 \\
\hline \multirow{3}{*}{5} & DAD1-DAD2 & -2.17 & -2.31 & -2.47 & -2.30 \\
\hline & DAD1-DAD3 & -1.74 & -1.90 & -2.09 & -1.88 \\
\hline & DAD2-DAD3 & -2.41 & -2.27 & -2.44 & -2.29 \\
\hline \multirow{3}{*}{95} & DAD1-DAD2 & 1.82 & 2.32 & 1.13 & 1.32 \\
\hline & DAD1-DAD3 & 0.15 & 0.17 & -0.27 & -0.06 \\
\hline & DAD2-DAD3 & -0.06 & -0.24 & -0.44 & -0.22 \\
\hline \multirow{3}{*}{99} & DAD1-DAD2 & 2.88 & 4.23 & 3.68 & 2.95 \\
\hline & DAD1-DAD3 & 0.71 & 0.94 & 0.71 & 0.58 \\
\hline & DAD2-DAD3 & 0.49 & 0.33 & 0.13 & 0.32 \\
\hline
\end{tabular}
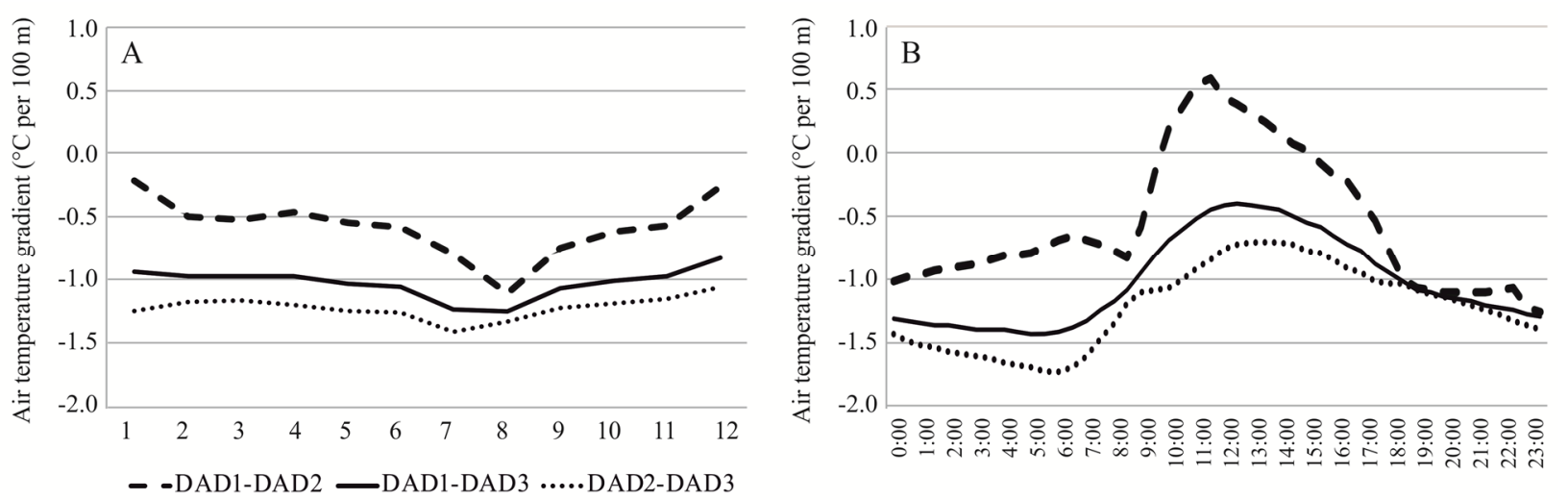

Fig. 5 The annual (A) and daily (B) variation of average air temperature gradients in the Upper Dades valley.

The annual variation of the gradients was similar to that specified in the entire studied valley (minimum in July $-1.41^{\circ} \mathrm{C}$ per $100 \mathrm{~m}$, maximum in December $-1.06^{\circ} \mathrm{C}$ per $\left.100 \mathrm{~m}\right)$. On the other hand, a high annual amplitude of the air temperature gradient was characteristic in the lower part of the studied valley (between $1600 \mathrm{~m}$ a.s.l. and $1750 \mathrm{~m}$ a.s.l., DAD1DAD2). In this range of altitude, only in August the mean monthly gradient exceeded $-1.0^{\circ} \mathrm{C}$ per $100 \mathrm{~m}$, but in the major part of the year it was around $-0.5^{\circ} \mathrm{C}$ per $100 \mathrm{~m}$. In January and December, the air temperature raised with an altitude of $0.2-0.3^{\circ} \mathrm{C}$ per $100 \mathrm{~m}$.

The daily variation of air temperature gradients in the upper part of the valley and between the lowest and highest stations was characterized by one minimum in the early morning hours and one maximum around midday (Fig. 5-B). Throughout the day, the thermal gradient was negative. The daily variation of the value of the air temperature gradient 
between the DAD1 and DAD2 stations was slightly different. Positive gradient values (temperature inversion) were recorded between $10 \mathrm{AM}$ and $3 \mathrm{PM}$ UTC. The temperature increase with altitude about noon (at 11:30 AM UTC) was $0.59^{\circ} \mathrm{C}$ per $100 \mathrm{~m}$. The greatest decrease in air temperature with altitude, amounting to $\sim-1.15^{\circ} \mathrm{C}$ per $100 \mathrm{~m}$, occurred around 8 PM UTC. It is worth noting that such a gradient value was then characteristic for the entire part of the studied valley. The daily variation of the values of air temperature gradients in individual seasons was similar to the average annual variation.

\subsection{Synoptic conditions of extreme values of the air temperature gradient}

One of the cases of extremely positive values of thermal gradient, indicated air temperature inversion occurred on February $4^{\text {th }}, 2013$ (Table 8). The mean daily thermal gradient in the lower part of the valley (DAD1-DAD2) was positive, whereas in the whole valley the thermal inversion occurred in some hours. The analysis of the retrograde trajectories showed that the source area of the air masses flowing over the study area was the North and Western Atlantic (Fig. 6-A). The air at an altitude of $500 \mathrm{~m}$ above the ground arrived to the research area from the south-east direction, and the air on the higher level arrived from the north. The influx of polar maritime air was related to the cyclonic circulation at the western end of the deep low-pressure area, which moved from Iceland to the Scandinavian Peninsula and strong high-pressure area developed that day over mid-Atlantic (Fig. 7-A).

The second case of positive values of thermal

Table 8 Extreme values of daily and instantaneous air temperature gradient between pairs of stations in the Upper Dades valley on days selected for the analysis of the synoptic situation.

\begin{tabular}{|c|c|c|c|c|c|c|c|}
\hline \multirow[b]{2}{*}{ Date } & \multicolumn{3}{|c|}{ Daily gradient $\left({ }^{\circ} \mathrm{C}\right)$} & \multirow[b]{2}{*}{ Hour } & \multicolumn{3}{|c|}{ Instantaneous gradient $\left({ }^{\circ} \mathrm{C}\right)$} \\
\hline & $\begin{array}{l}\text { DAD1- } \\
\text { DAD2 }\end{array}$ & $\begin{array}{l}\text { DAD1- } \\
\text { DAD3 }\end{array}$ & $\begin{array}{l}\text { DAD2- } \\
\text { DAD3 }\end{array}$ & & $\begin{array}{l}\text { DAD1- } \\
\text { DAD2 }\end{array}$ & $\begin{array}{l}\text { DAD1- } \\
\text { DAD3 }\end{array}$ & $\begin{array}{l}\text { DAD2- } \\
\text { DAD3 }\end{array}$ \\
\hline 4.02 .2013 & 0.99 & -0.69 & -0.19 & 16.00 & 1.90 & 2.04 & 2.09 \\
\hline 30.04 .2013 & 1.05 & -1.01 & -0.40 & 12.00 & 4.26 & 2.08 & 1.17 \\
\hline 15.06 .2014 & -0.93 & -1.41 & -1.61 & 17.30 & -3.48 & -3.39 & $-3 \cdot 36$ \\
\hline 15.08 .2015 & -1.39 & -1.32 & -1.30 & 17.30 & -3.44 & -3.10 & -2.95 \\
\hline
\end{tabular}

A

\section{NOAA HYPSLIT MODEL}

Backward trajectories ending at 16:00 UTC 04 Feb 13 GHDA Meteorological Data

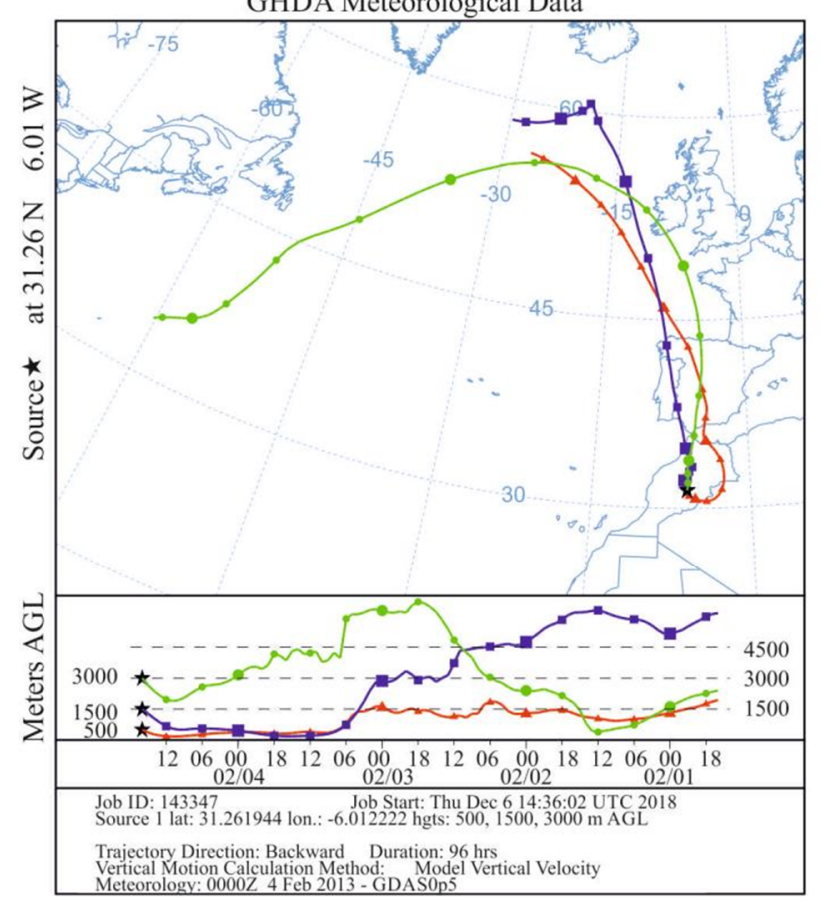

B

NOAA HYPSLIT MODEL

Backward trajectories ending at 12:00 UTC 30 Apr 13 GHDA Meteorological Data

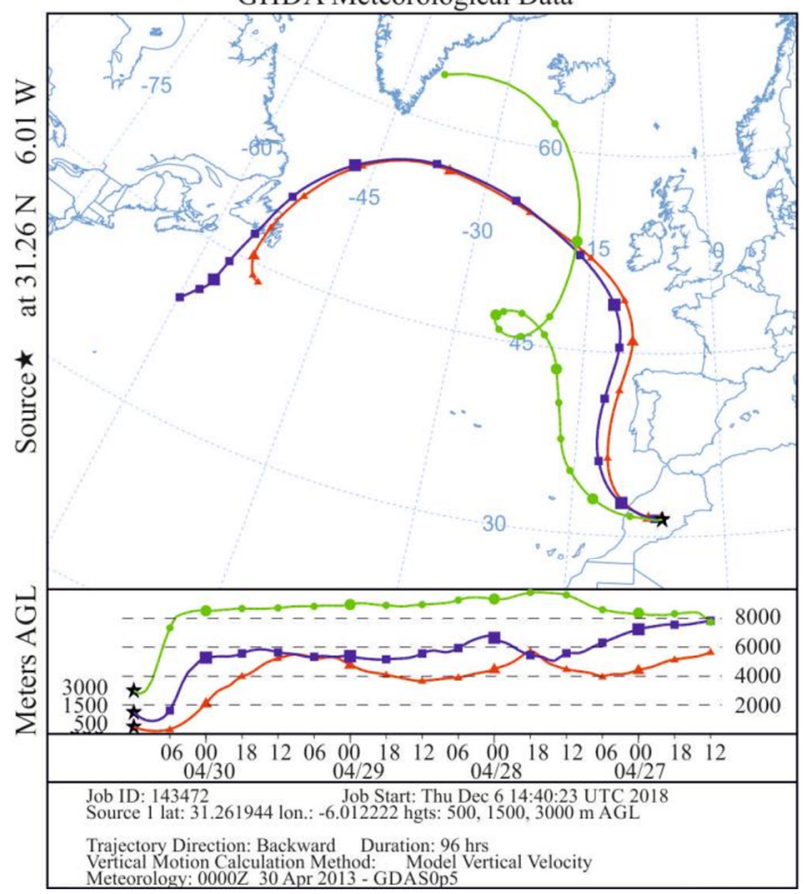

Fig. 6 Backward trajectories ending on days with extremely positive values of air temperature gradient indicated air temperature inversion (A - February $4^{\text {th }}, 2013, \mathrm{~B}$ - April $30^{\text {th }}$, 2013) (source: NOAA). Colour lines of backward trajectories represent different elevations above ground level (AGL) in the chosen location. 

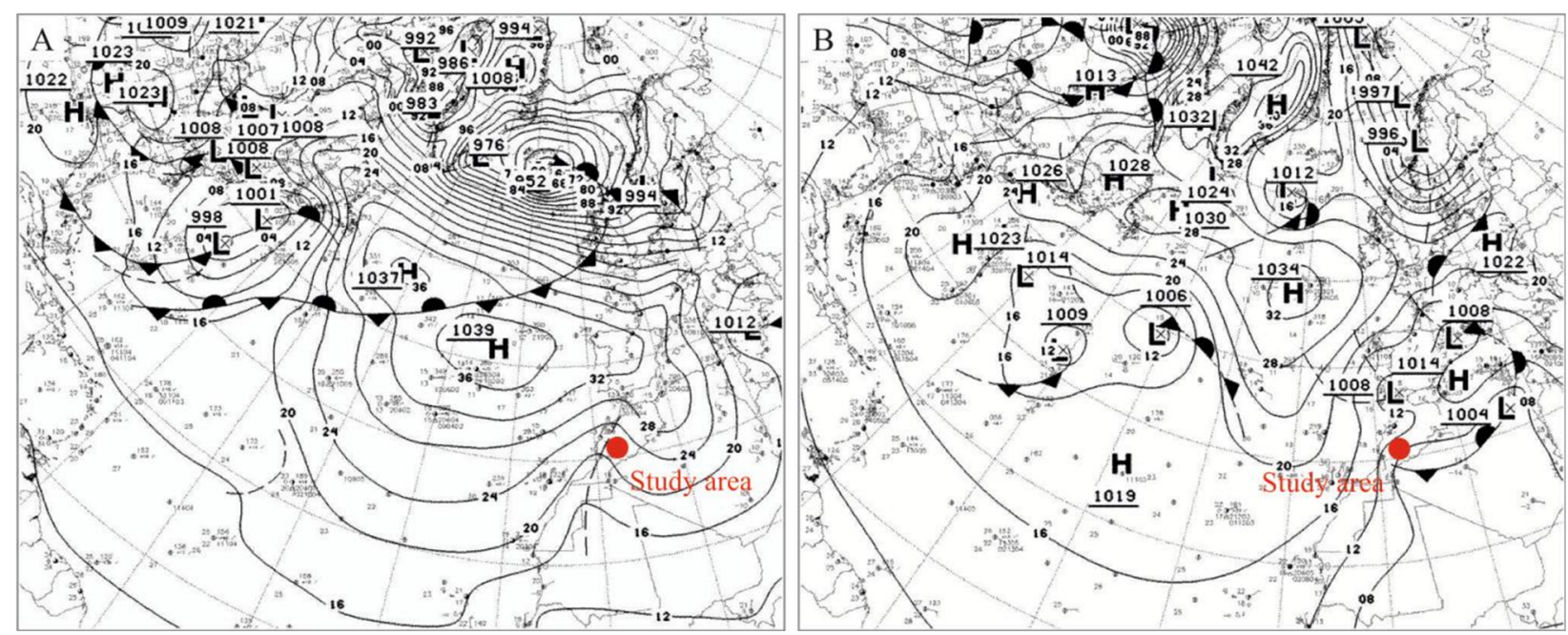

Fig. 7 Synoptic situation on days with extremely positive values of air temperature gradient indicated air temperature inversion (A - February $4^{\text {th }}, 2013$, B - April 30 $30^{\text {th }}, 2013$ ) (source: Wetterzentrale.de).

gradient selected for analysis occurred on April $30^{\text {th }}$, 2013. They were rather poorly developed (with a slight pressure difference) and accompanied in the western part by the occlusion fronts. The air masses reaching the research area on that day came from the Western and North Atlantic (Fig. 6-B). The source area of the air masses in the lower troposphere was the ocean off the coast of Newfoundland, and at an altitude of $3000 \mathrm{~m}$ above the ground surface - the ocean off the east coast of Greenland. The entire journey of the air masses in this case, up to the inflow over the area of Morocco, was over the water surface. On that day, there were highs and lows located close to each other over the western Mediterranean basin and the North Atlantic (Fig. 7-B). The first air mass flowed in on the south side of the low-pressure area developed south of Greenland, the second mass flowed around it from the east. Streams of air flowed over the research area from the west, east of a strong high-pressure area developed in the mid-Atlantic, and west of the occlusion fronts accompanying the Mediterranean baric systems.

A high negative values of thermal gradient in the Upper Dades valley occurred on June $15^{\text {th }}, 2014$ (Table 8). The western part of the Mediterranean Sea and western part of Europe was within the range of the lows which directed air masses in the lower layer of the atmosphere to the west (Figs. 8-A and 9-A). The air between 1500 and $3000 \mathrm{~m}$ above ground surface came from the Atlantic. The air flowed along the shoreline, reaching the Upper Dades valley from the southwest, along the valley axis.

Another case of a high negative value of air temperature gradient occurred on August $15^{\text {th }}, 2015$ (Table 8). The area of northwest Africa was within the wedge of the vast Azores high-pressure area. On its edge near the earth's surface, air masses were flowing over the studied area from the north, from the coast of Portugal (Figs. 8-B and 9-B). In the medium troposphere, advection took place, as in the previous case, from the opposite direction - from the western part of the Sahara i.e. Mauretania and Mali (Fig. 9-B).

\subsection{Thermal inversion}

The results show that the greatest percent of time (17.7\%) with thermal inversions was recorded in the lower part of the study area (DAD1-DAD2). The longest period with thermal inversions occurred in winter months (Dec. - Jan.), but the strongest thermal inversions were recorded in late spring and first half of summer (Apr. - Jun.) (Fig. 10-A). The maximum instantaneous thermal inversion recorded during period of investigation was within the range from 6 to $8{ }^{\circ} \mathrm{C}$ per $100 \mathrm{~m}$ during the whole year with a maximum in June. The annual variability of inversion is partially consistent with the annual variation of cloud cover. In some months of high cloudiness (Mar. - Jun. and Sept. - Nov.) the occurrence of thermal inversions increased which could indirectly indicate the role of latent heat emitted during water vapour condensation at the level of about $1800 \mathrm{~m}$ a.s.l. in creating the inversion layer. However, the occurrence of thermal inversions is the lowest in summer (Jul. Sep.), while in winter months with reduced cloudiness (Dec. - Jan.) the occurrence of thermal inversions is 
A

Backward trajectories ending at 17:00 UTC 15 Jun 14 GFSG Meteorological Data

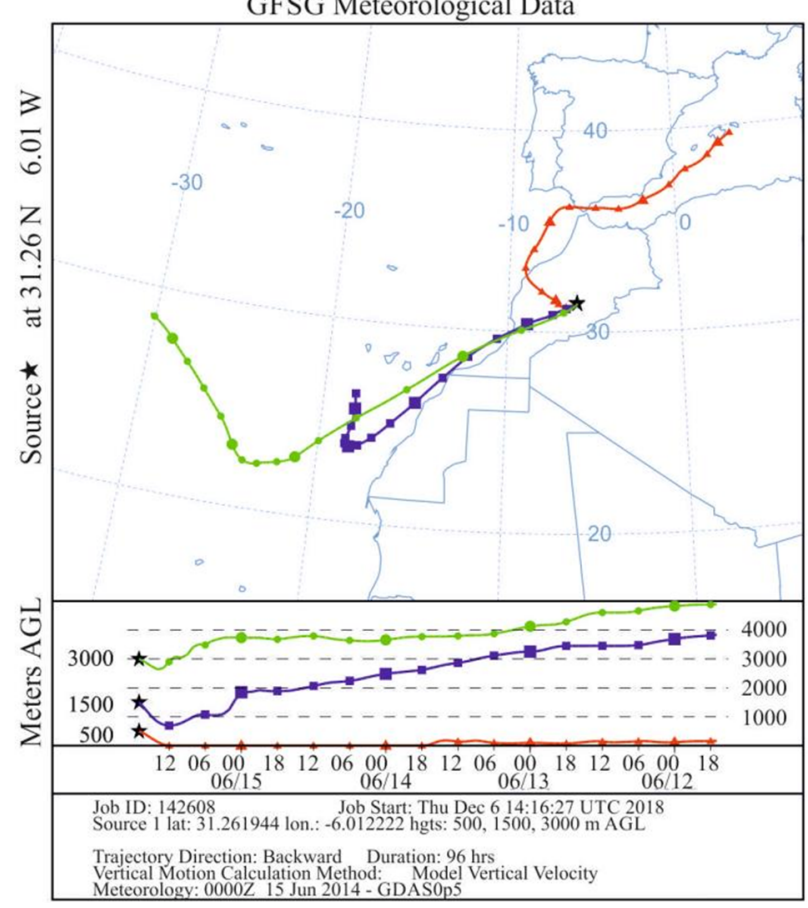

B Backward trajectories ending at 17:00 UTC 15 Aug 15 GFSG Meteorological Data

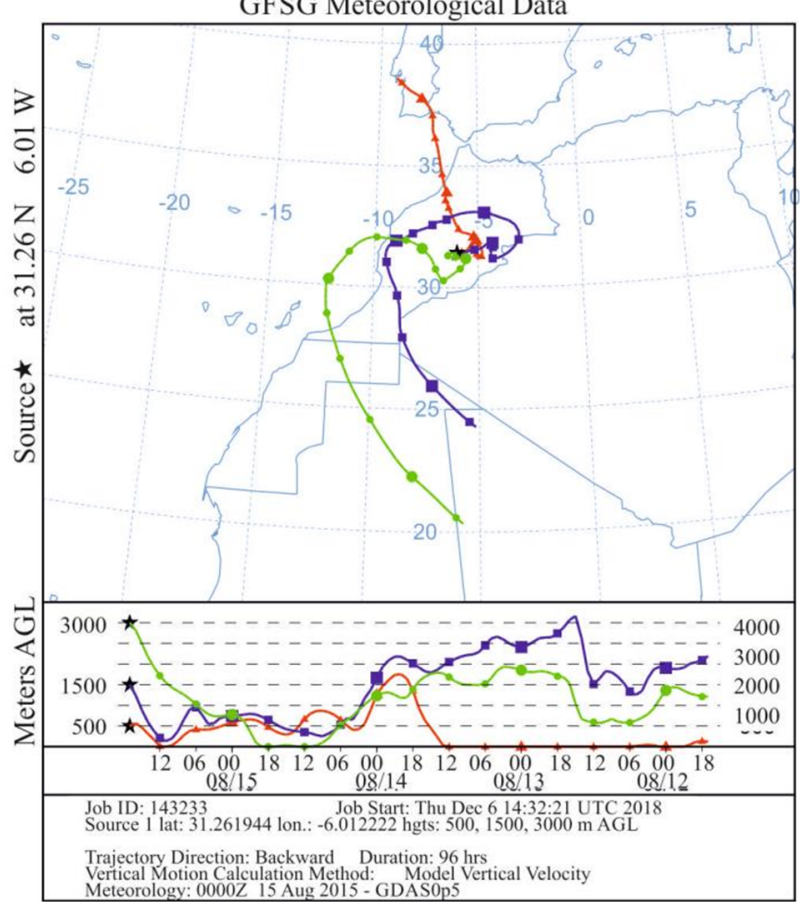

Fig. 8 Backward trajectories ending on days with extremely negative values of the air temperature gradient (A - June $15^{\text {th }}, 2014, \mathrm{~B}$ - August $15^{\text {th }}, 2015$ ) (source: NOAA). Colour lines of backward trajectories represent different elevations above ground level (AGL) in the chosen location.
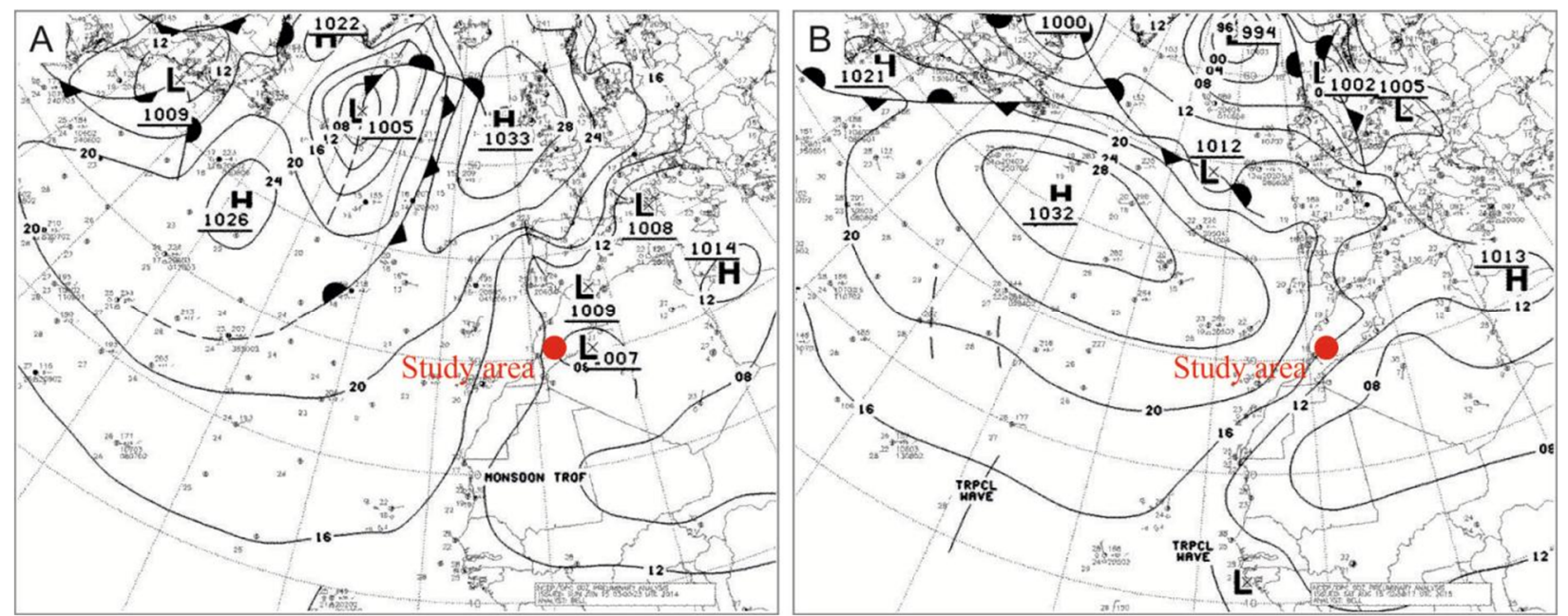

Fig. 9 Synoptic situation on days with extremely negative values of the air temperature gradient (A - June $15^{\text {th }}$, 2014, B - August $15^{\text {th }}, 2015$ ) (source: Wetterzentrale.de).

the highest. Due to the lack of data on the relative air humidity at different levels, it is not possible to confirm the dependence between temperature inversions and the condensation of water vapour.

The diurnal variability of thermal inversions was characterized by a clear maximum around midday. The strongest inversions (with thermal gradient values above $2^{\circ} \mathrm{C}$ per $100 \mathrm{~m}$ ) also occurred during this time of the day (Fig. 10B). Temperature inversions occurred rarely during the night, which suggests that most of the inversions in the study area are not radiation-related.

There was no clear relationship between strong thermal inversions (with a thermal gradient above $2{ }^{\circ} \mathrm{C}$ per $100 \mathrm{~m}$ ) and precipitation. In four cases, no precipitation occurred at any of the stations. In two 

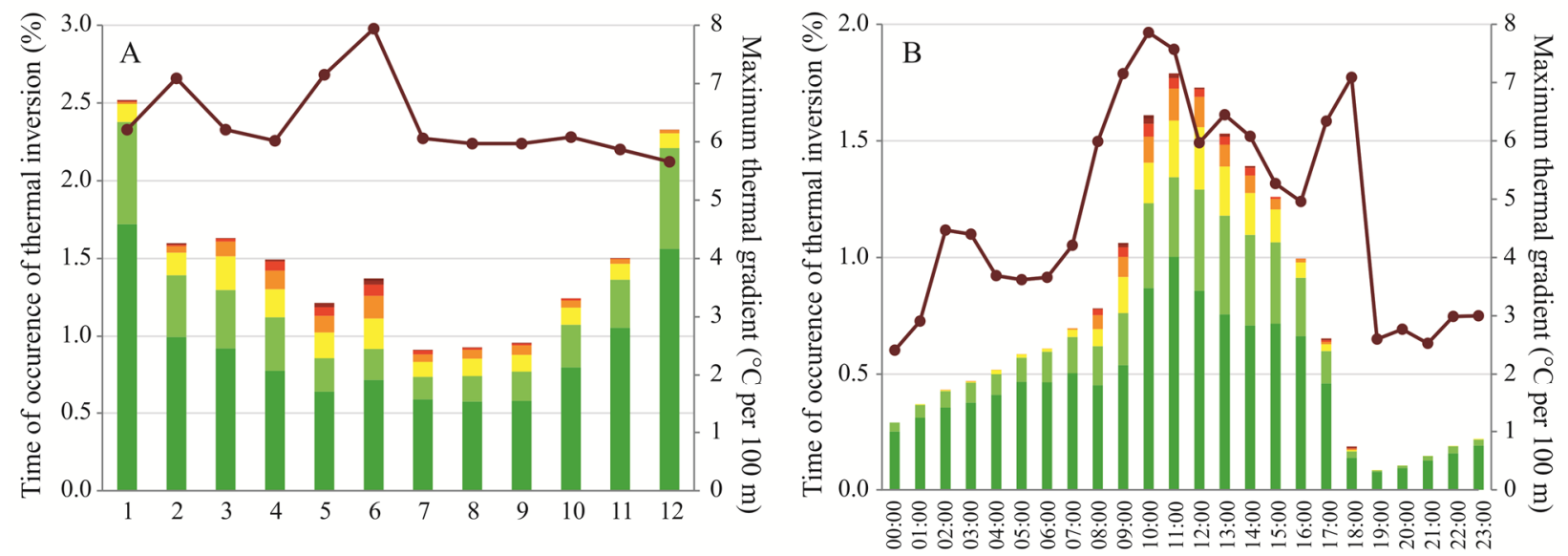

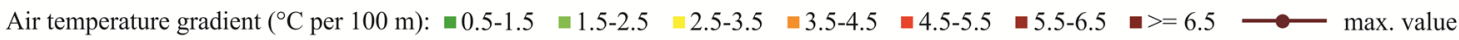

Fig. 10 Monthly (A) and daily (B) time occurrence of thermal inversions with the value of the air temperature gradients and the maximum thermal gradient ever recorded for the lower part of the valley (DAD1-DAD2). Weak inversions (thermal gradient below $0.5^{\circ} \mathrm{C}$ per $100 \mathrm{~m}$ ) were not taken into account due to the accuracy of the temperature sensors used.

cases, a strong inversion occurred before heavy rain recorded at $\mathrm{DAD} 2$ station. In one case, the inversion occurred after precipitation at the DAD2 station. No precipitation was found at the DAD1 station in any of the discussed cases, and all cases with precipitation at the DAD2 station occurred in the summer months (June-August). The lack of dependence of thermal inversion on precipitation may constitute a premise for rejecting the emission of latent heat from water vapour condensation as one of the decisive factors influencing the development of a positive thermal gradient.

The retrograde trajectories of air particles analysed with the use of the HYSPLIT models shows, that in the cases of strongest thermal inversion (max. recorded instantaneous air temperature gradients was equal to $5.28^{\circ} \mathrm{C}$ per $100 \mathrm{~m}$ on September $17^{\text {th }}, 2013$ and $2.64^{\circ} \mathrm{C}$ per $100 \mathrm{~m}$ on August $19^{\text {th }}, 2014$ ) advection from the south and south-west direction dominated, i.e. along the axis of the Upper Dades valley (Figs. 11A and $\mathrm{B}$ ). In these days in the lower (DAD1) and middle (DAD2) parts of the Upper Dades valley we observed the fully overcast sky and occurrence of dust storm, whereas in the upper part of the valley the sky was clear with no visible sign of dust storm. In the second case, 4 hours after the maximum air temperature inversion the heavy rain occurred in DAD2 station (28.8 $\mathrm{mm}$ in 1 hour and 2 minutes).

The synoptic situations in both cases were almost similar (Fig. 12). The influx of dry hot air from the western part of the Sahara along the valley axis was related to the anticyclonic circulation resulted from the occurrence of low-pressure areas developed over western Sahara, western Mediterranean basin, western Europe, and the deep low-pressure area developed over Scandinavian peninsula, and a strong high-pressure area developed in the mid-Atlantic.

\section{Discussion}

Studies on the air temperature gradient in mountains have highlighted key factors, besides altitude, that affect the results, e.g. land cover, slope exposure, substrate rocks (discussed below) which all impact the net radiation and air flow in the macroand the mesoscale (Alisov et al. 1952; Qiyao 1988; Whiteman et al. 1989; Barry 1992; Mahrt 2006; Zheng et al. 2009; Rist et al. 2020). Our research was designed to minimize the influence of such factors, because all meteorological stations were located at the floor of a long and wide mountain valley (no difference in slope exposure), in places covered by the same type of vegetation. The only factor, besides altitude, which influences the thermal gradient was the synoptic situation (inflow of different air masses), frequently associated with the season of the year.

The process that significantly modifies the thermal gradient values in the Upper Dades valley can be the supply of latent heat of condensation (formation of clouds and precipitation). Moreover, in the lower and middle part of the valley, it is sometimes cooler in the afternoon hours than in the upper one, which is related to the influence of dust storms limiting sunlight (dust storms generally do not 
A Backward trajectories ending at 08:00 UTC 17 Sep 13 GFSG Meteorologiçal Data

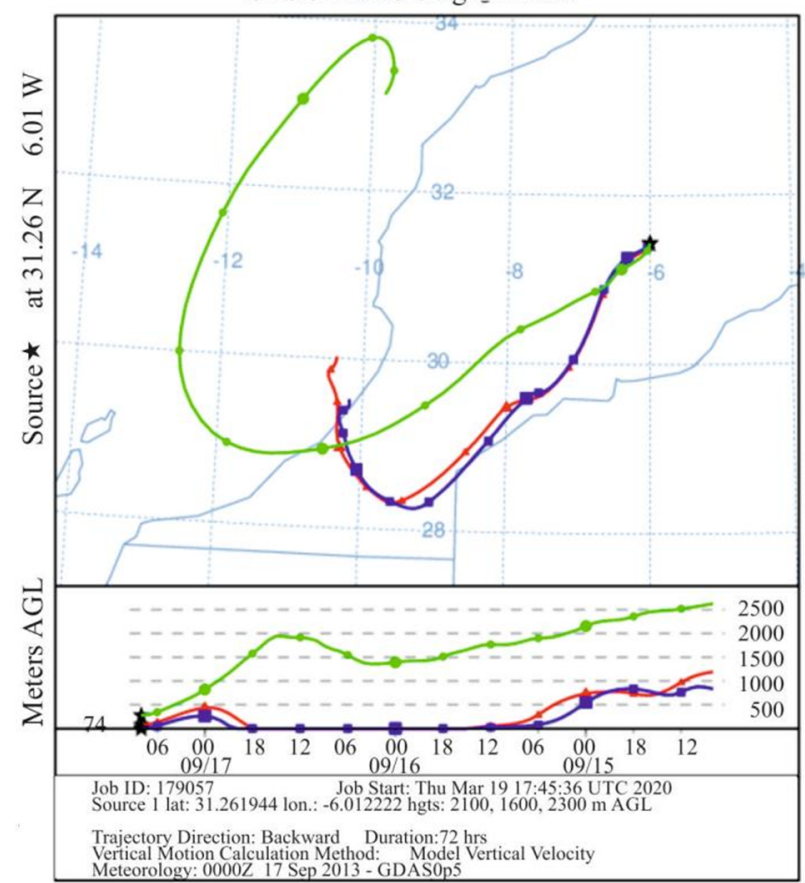

$\mathrm{B}$

NOAA HYPSLIT MODEL

Backward trajectories ending at 15:00 UTC 19 Aug 14

GFSG Meteorological Data

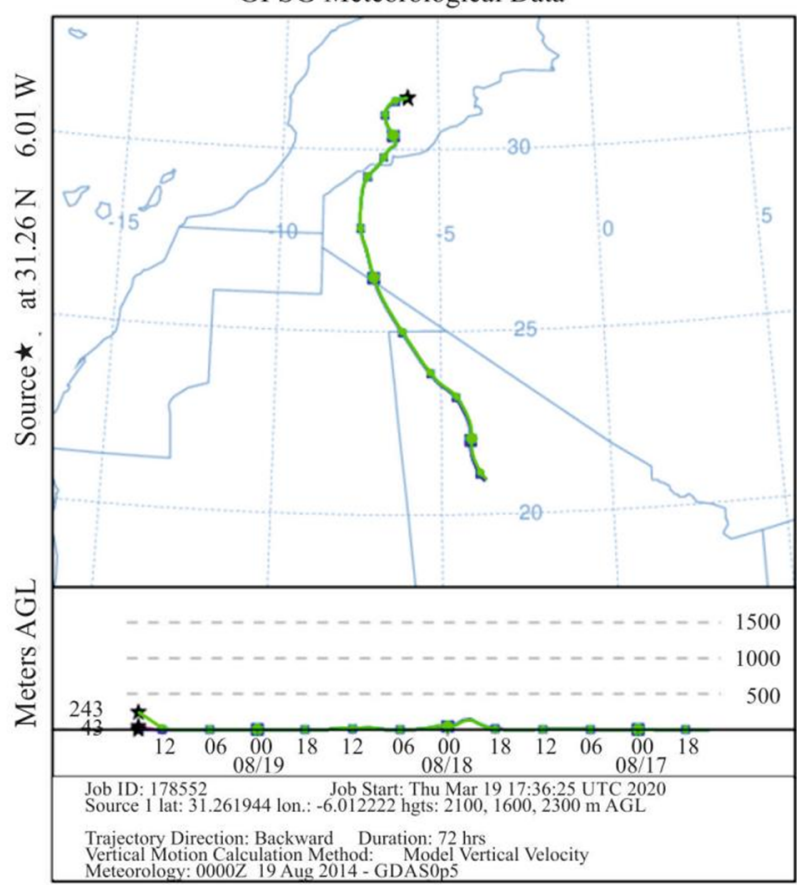

Fig. 11 Backward trajectories ending on days with extremely positive values of air temperature gradient indicated air temperature inversion and advection from the south and south-west direction (A - September $17^{\text {th }}, 2013$, B - August $19^{\text {th }}$, 2014) (source: NOAA). Colour lines of backward trajectories represent different elevations above ground level (AGL) in the chosen location.
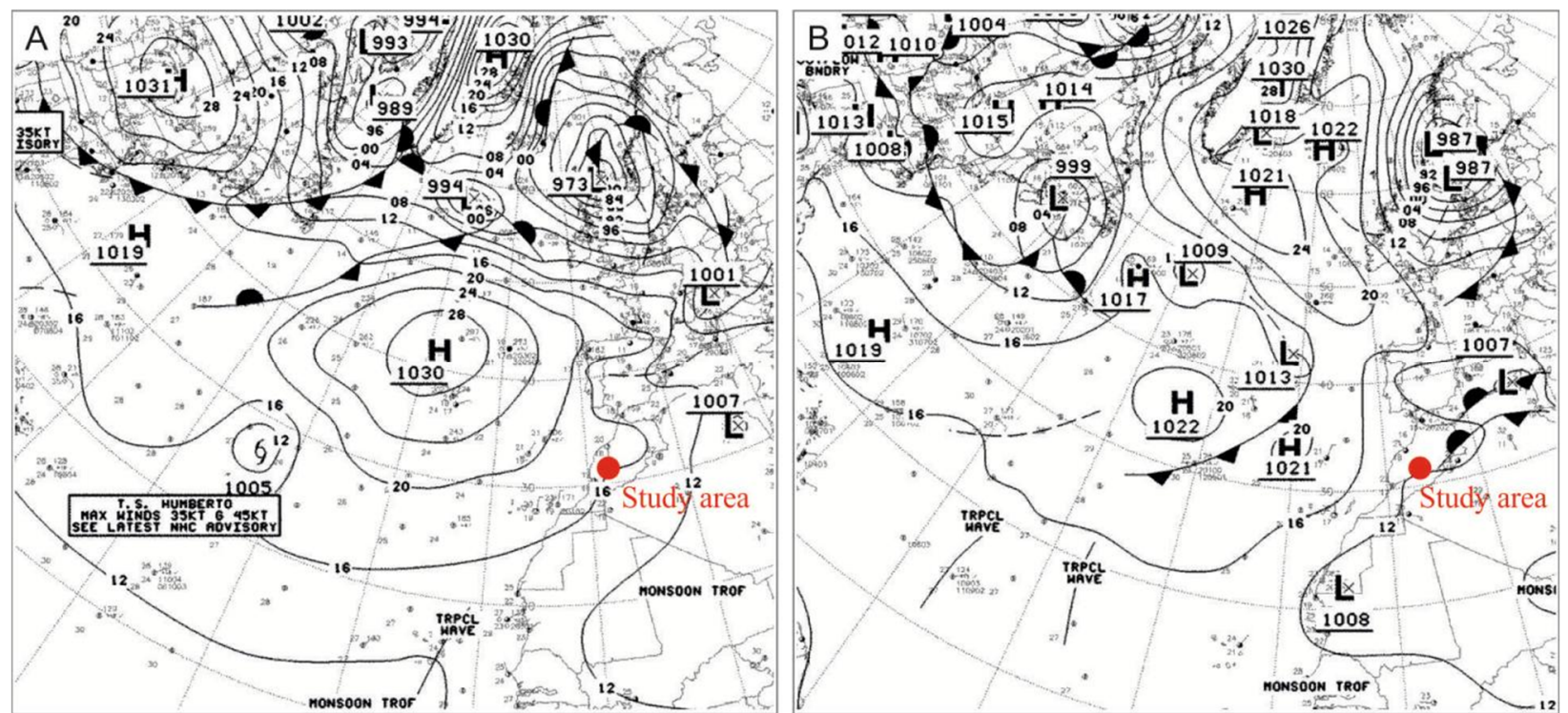

Fig. 12 Synoptic situation on days with extremely positive values of air temperature gradient indicated air temperature inversion and advection from the south and south-west direction (A - September 17 ${ }^{\text {th }}, 2013$, B - August $19^{\text {th }}, 2014$ ) (source: Wetterzentrale.de).

reach high altitudes). The advection factor is probably responsible for extremely high values of air temperature gradients: the inflow of air masses at different altitudes with different physical properties.
Large inter-annual variations of monthly gradients obtained in this study, with the highest gradients in winter months and lower in summer, support finding from mountains of other climatic 
zones, e.g. from Alps in Europe (Rolland 2003; Dumas 2013; Rist et al. 2020), Tianshan in Central Asia (Gheyret et al. 2020) or Rocky Mountains (Blandford et al. 2008). Such pattern can be explained by the cold air pools resulting in temperature inversion in the mountain valleys. In the Arctic this phenomenon can result in the air temperature inversion which was well shown by Ambrožová and Láska (2017).

The spatial distribution of the thermal gradient is significantly influenced by the position of the slopes in relation to the dominant wind directions (windward and leeward side) (Minder et al. 2010). Manabe and Strickler (1964) indicate cloud cover and carbon dioxide content and Lundquist et al. (2008), Marshall and Sharp (2009) and Gouvas et al. (2011) air turbidity and wind speed as important factors influencing the pattern of thermal gradients. Friedman (1966) shows that the thermal gradient in the mountains may have different values due to the occurrence of gravitational waves in the atmosphere, which, apart from thermal stratification, also depend on the course of landform features. According to Blandford et al. (2008) significant variations from the environmental lapse rate constant occur in mountains depending on the season and synoptic conditions, and our findings fully support this statement.

The obtained results confirm that in the arid mountains the thermal altitudinal gradients are high (Alisov et al. 1952; Yacono 1968; Barry 1992). Moreover, they support previous finding that in arid climates, the gradient values above high mountain deserts and above high plateaus are usually highly dependent of the season. For example, in the Ahaggar mountains, the average air temperature drops only by $0.5^{\circ} \mathrm{C}$ per $100 \mathrm{~m}$ in January but under more synoptically unstable conditions in July it increased to $0.8^{\circ} \mathrm{C}$ per $100 \mathrm{~m}$ (Yacono 1968). Similar pattern was found by us in the Upper Dades valley. On the other hand, Minder et al. (2010) shows that in the Cascade Mountains, the highest values of the thermal gradient

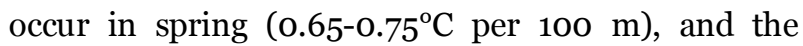

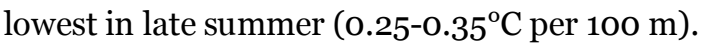

The number of stations used in this work is limited (only three stations which do not cover the entire altitudinal range of the valley) as well as the 5year period of data collection. However, the remoteness of the area and unstable socio-economic environment pose a significant logistic and safety challenges for field-based long-term measurements.

\section{Conclusions}

The average thermal gradient in the Upper Dades valley was $-1.02^{\circ} \mathrm{C}$ per $100 \mathrm{~m}$ for the 5 -year period with the highest values recorded in winter and the lowest in summer seasons. The greatest variability of air temperature gradient was recorded also in winter and the lowest in summer. The annual amplitude of the air temperature gradient was the greatest in the lower part of the valley. In winter, frequent inversion of air temperature gradient was recorded. On the other hand, the strongest thermal inversions were recorded in late spring and first half of summer.

In the Upper Dades valley minima of the daily variability of air temperature gradients were observed in early morning hours and maxima around midday. In the lower part, air temperature inversion frequently developed between $10 \mathrm{AM}$ and 3 PM UTC. The daily average variability of air temperature gradients in the individual seasons were similar to the average annual variability.

The processes that can significantly modify the thermal stratification and can influence air temperature inversion are probably the supply of latent heat of condensation and occurrence of dust storms. The adiabatic increase in air temperature during its descent within the high-pressure area was greater in the free atmosphere (between 1200 and $2000 \mathrm{~m}$ a.s.l.) than near the ground surface. A warm inversion layer formed as the trade wind inversion. This layer inhibited the development of convection currents from the ground, limiting the formation of clouds and precipitation.

Our finding prove that in the arid mountains the thermal altitudinal gradients are high and that they are highly dependent of the season and synoptic situation. Inflow of air masses with different physical properties results in extreme gradients.

\section{Acknowledgement}

This study was in part financed by the National Science Centre, Poland, project no. UMO2011/01/B/ST10/07295. The authors are grateful to Mohammed, Hamid and Ibrahim for their help in the field and maintenance of weather stations in the Upper Dades valley, Morocco. We thank three anonymous reviewers whose comments have helped us in improving the manuscript. 
Open Access This article is licensed under a Creative Commons Attribution 4.0 International License, which permits use, sharing, adaptation, distribution and reproduction in any medium or format, as long as you give appropriate credit to the original author(s) and the source, provide a link to the Creative Commons license, and indicate if changes were made. The images or other third party material in this article are included in the

\section{References}

Acevedo OC, Fitzjarrald DR (2001) The early evening surfacelayer transition: Temporal and spatial variability. J Atmos Sci 58: $2650-2667$.

https://doi.org/10.1175/15200469(2001)058<2650:TEESLT>2.0.CO;2

Alam K, Qureshi S, Blaschke T (2011) Monitoring spatiotemporal aerosol patterns over Pakistan based on MODIS, TOMS and MISR satellite data and a HYSPLIT model. Atmos Environ 45(27): 4641-4651. https://doi.org/10.1016/j.atmosenv.2011.05.055

Alisov BP, Drozdov OA, Rubinshtein ES (1952) Course on Climatology. Part I, II. Gidrometeoizdat: Leningrad p 487. (In Russian)

Ambrožová K, Láska K (2017) Air temperature variability in the vertical profile over the coastal area of Petuniabukta, central Spitsbergen. Pol Polar Res 38(1): 41-60. https://doi.org/10.1515/popore-2017-0004

Bacardit M, Camarero L (2009) Fluxes of Al, Fe, Ti, Mn, Pb, Cd, $\mathrm{Zn}, \mathrm{Ni}, \mathrm{Cu}$, and As in monthly bulk deposition over the Pyrenees (SW Europe): The influence of meteorology on the atmospheric component of trace element cycles and its implications for high mountain lakes. $J$ Geophys Res 114(GooDo2): 1-17. https://doi.org/10.1029/2008JGo00732

Barry RG (1992) Mountain weather and climate, Routledge, London and New York. p 402.

Barry RG, Chorley RJ (2003) Atmosphere, Weather and Climate, $8^{\text {th }}$ ed. Routledge: London p 460.

Blandford TR, Harshburger BJ, Humes KS, et al. (2005) Interpolating surface air temperature for use in semidistributed snowmelt runoff models. Proceeding of Western Snow Conference, Great Falls Montana: 117-122.

Blandford TR, Humes KS, Harshburger BJ, et al. (2008) Seasonal and synoptic variations in near-surface air temperature lapse rates in a mountainous basin. J Appl Meteorol Climatol 47: 249-261 https://doi.org/10.1175/2007JAMC1565.1

Cappy S (2006) Hydrogeological characterization of the Upper Drâa catchment (Morocco). Unpublished $\mathrm{PhD}$ thesis, Geological Institute, Faculty of Mathematics and Natural Sciences, University of Bonn. p 190.

Chutko KJ, Lamoureux SF (2009) The influence of low-level thermal inversions on estimated melt-season characteristics in the central Canadian Arctic. Int J Climatol 29(2): 259-268. https://doi.org/10.1002/joc.1722

Collados-Lara AJ, Fassnacht SR, Pulido-Velazquez D, et al. (2021a) Intra-day variability of temperature and its nearsurface gradient with elevation over mountainous terrain: Comparing MODIS land surface temperature data with coarse and fine scale near-surface measurements. Int $\mathrm{J}$ Climatol 41(S1): E1435-E1449. https://doi.org/10.1002/joc.6778

Collados-Lara AJ, Fassnacht SR, Pardo-Igúzquiza E, et al. (2021b) Assessment of high resolution air temperature fields at rocky mountain national park by combining scarce point measurements with elevation and remote sensing data. article's Creative Commons license, unless indicated otherwise in a credit line to the material. If material is not included in the article's Creative Commons license and your intended use is not permitted by statutory regulation or exceeds the permitted use, you will need to obtain permission directly from the copyright holder. To view a copy of this license, visit http://creativecommons.org/licenses/by/4.o/.
Remote Sens 13(1): 113.

https://doi.org/10.3390/rs13010113

de Jong C, Machauer R, Leavesely G, et al. (2005) Integrated hydrological modelling concepts for a peripheral mountainous semi-arid basin in southern Morocco. In: Escadafal R, Paracchini ML (eds.), Geomatics for Land and Water Management: Achievements and Challenges in the Euromed Context. EC JRC Workshop proceedings: 219-227.

Dłużewski M, Krzemień K, Rojan E, et al. (2013) Stream channel development in the southern parts of the High Atlas Mountains, Morocco. Geografija 49(1): 10-21. https://doi.org/10-21. 10.6001/geografija.v49i1.2653

Draxler RR, Taylor AD (1982) Horizontal Dispersion Parameters for Long-Range Transport Modeling. J Appl Meteorol Climatol 21: 367-372. https://doi.org/10.1175/1520-0450(1982)021

Dumas D (2013) Changes in temperature and temperature gradients in the French Northern Alps during the last century. Theor Appl Climatol 111: 223-233. https://doi.org/10.1007/s00704-012-0659-1

Escudero M, Stein AF, Draxler RR, et al. (2010) Source apportionment for African dust outbreaks over the Western Mediterranean using the HYSPLIT model. Atmos Res 99 (34): $518-527$.

https://doi.org/10.1016/j.atmosres.2010.12.002

Fink AH, Knippertz P (2003) An extreme precipitation event in southern Morocco in spring 2002 and some hydrological implications. Weather 58: 377-392. https://doi.org/10.1256/wea.256.02.

Fiorella RP (2015) Spatiotemporal variability of modern precipitation $\delta^{18} \mathrm{O}$ in the central Andes and implications for paleoclimate and paleoaltimetry estimates. J Geophys Res Atmos 120: 4630-4656. https://doi.org/10.1002/2014JD022893

Formenti P, Andreae MO, Andreae TW, et al. (2001) Aerosol optical properties and large-scale transport of air masses: observations at a coastal and a semiarid site in the eastern Mediterranean during summer 1998. J Geophys Res Atmos 106 (D9): 9807-9826.

Friedman JP (1966) Propagation of internal gravity waves in a thermally stratified atmosphere. J Geophys Res 71(4): 10331054 .

Gheyret G, Mohammat A, Tang Z (2020) Elevational patterns of temperature and humidity in the middle Tianshan Mountain area in Central Asia. J Mt Sci 17(2): 397-409. https://doi.org/10.1007/s11629-019-5481-0

Gouvas MA, Sakellariou NK, Kambezidis HD (2011) Estimation of the monthly and annual mean maximum and mean minimum air temperature values in Greece. Meteorol. Atmospheric Phys. 110: 143-149. https://doi.org/10.1007/s00703-010-0111-y

Hadria R, Benabdelouahab T, Mahyou H, et al. (2018) Relationships between the three components of air temperature and remotely sensed land surface temperature of agricultural areas in Morocco. Int J Remote Sens 39(2): 356373 . 
https://doi.org/10.1080/ 01431161.2017.1385108

Hann J, Süring R (eds.) (1939) Textbook of Meteorology - First Volume. Willibald Keller publisher, Leipzig. p 480. (in German)

Immerzeel WW, Petersen L, Ragettli S, et al. (2014) The importance of observed gradients of air temperature and precipitation for modeling runoff from a glacierized watershed in the Nepalese Himalayas. Water Resour Res 50: 2212-2226.

https://doi.org/10.1002/2013WR014506

Kattel DB, Yao T, Yang K, et al. (2013) Temperature lapse rate in complex mountain terrain on the southern slope of the central Himalayas. Theor Appl Climatol 113(3-4): 671-682. https://doi.org/10.1007/s00704-012-0816-6

Kattel DB, Yao T (2018) Temperature-topographic elevation relationship for high mountain terrain: an example from the southeastern Tibetan Plateau. Int J Climatol 38(Suppl.1): e901-e920.

https://doi.org/10.1002/joc.5418

Liston GE, Pielke Sr, RA, Greene EM (1999) Improving firstorder snow-related deficiencies in a regional climate model. $\mathrm{J}$ Geophys Res Atmos 104(19): 559-567. https://doi.org/10.1029/1999JD900055

Lundquist JD, Pepin N, Rochford C (2008) Automated algorithm for mapping regions of cold-air pooling in complex terrain. J Geophys Res Atmos 113(D22107): 1-15 https://doi.org/10.1029/2008JDo09879

Malek E, Davis T, Martin RS, et al. (2006) Meteorological and environmental aspects of one of the worst national air pollution episodes (January, 2004) in Logan, Cache Valley, Utah, USA. Atmos Res 79: 108-122.

https://doi.org/:10.1016/j.atmosres.2005.05.003

Mahrt L (2006) Variation of Surface Air Temperature in Complex Terrain. J Appl Meteorol Climatol 45: 1481-1493. https://doi.org/10.1175/JAM2419.1

Manabe S, Strickler RF (1964) Thermal equilibrium of the atmosphere with a convective adjustment. J Atmos Sci 21: 361-384.

Marshall SJ, Sharp MJ (2009) Temperature and melt modeling on the Prince of Wales Ice Field, Canadian High Arctic. J Clim 22(6): 1454-1468,

https://doi.org/10.1175/2008JCLI2560.1

Minder JR, Mote PW, Lundquist JD (2010) Surface temperature lapse rates over complex terrain: Lessons from the Cascade Mountains. J Geophys Res Atmos 115: D14122. https://doi.org/10.1029/2009JD013493

Qiyao L (1988) A method of calculating the monthly and annual mean temperatures in mountainous area. Acta Geogr Sin 43(3): 213-223. https://doi.org/10.11821/xb198803003 (In Chinese)

Palarz A, Celinski-Mysław D (2017) The effect of temperature inversions on the particulate matter PM10 and sulfur dioxide concentrations in selected basins in the Polish Carpathians. Carpathian J Earth Environ Sci 12: 629-640.

Petersen L, Pellicciotti F (2011) Spatial and temporal variability of air temperature on a melting glacier: Atmospheric controls, extrapolation methods and their effect on melt modeling, Juncal Norte Glacier, Chile. J Geophys Res Atmos 116: D23109.

https://doi.org/10.1029/2011JD015842

Rahman SA, Hamzah MS, Elias MS, et al. (2015) A long term study on characterization and source apportionment of particulate pollution in Klang Valley, Kuala Lumpur. Aerosol Air Qual Res 15: 2291-2304.

https://doi.org/10.4209/aaqr.2015.03.0188

Ragettli S, Pellicciotti F, Bordoy R, et al. (2013) Sources of uncertainty in modeling the glacio-hydrological response of a Karakoram watershed to climate change. Water Resour Res 49: 1-19.

https://doi.org/10.1002/wrcr.20450

Rist A, Roth L, Veit H (2020) Elevational ground/air thermal gradients in the Swiss inner Alpine Valais. Arct Antarct Alp Res 52(1): 341-360.

https://doi.org/10.1080/15230430.2020.1742022

Rojan E, Dłużewski M, Krzemień K (2020) Sediment budget of high mountain stream channels in an arid zone (High Atlas Mountains, Morocco). Catena 190: 1-17.

https://doi.org/10.1016/j.catena.2020.104530

Rolland C (2003) Spatial and seasonal variations of air temperature lapse rates in alpine regions. J Clim 16(7): 10321046.

https://doi.org/10.1175/1520-

0442(2003)016<1032:SASVOA >2.0.CO;2

Schulz O, de Jong C (2004) Snowmelt and sublimation: field experiments and modelling in the High Atlas Mountains of Morocco. Hydrol Earth Syst Sci 8(6): 1076-1089. http://dx.doi.org/10.5194/hess-8-1076-2004

Schulz O, Busche H, Benbouziane A (2008) Decadal Precipitation Variances and Reservoir Inflow in the Semi-Arid Upper Drâa Basin (South-Eastern-Morocco). In: Zereini F, Hötzl H (eds.), Climatic Changes and Water Resources in the Middle East and in North Africa. Springer, Berlin, Heidelberg: 165-178.

http://dx.doi.org/10.1007/978-3-540-85047-2_13.

Silcox GD, Kelly KE, Crosman ET, et al. (2012) Wintertime PM2.5 concentrations during persistent, multi-day cold-air pools in a mountain valley. Atmos Environ 46: 17-24. https://doi.org/10.1016/j.atmosenv.2011.10.041

Stein AF, Draxler RR, Rolph GD, et al. (2015) NOAA's HYSPLIT Atmospheric Transport and Dispersion Modeling System. Bull Am Meteorol Soc 96 (12): 2059-2077. https://doi.org/10.1175/BAMS-D-14-00110.1

Stokes M, Mather AE (2015) Controls on modern tributaryjunction alluvial fan occurrence and morphology: High Atlas Mountains, Morocco. Geomorphology 248: 344-362. https://doi.org/10.1016/j.geomorph.2015.08.003

Whiteman CD, Allwine KJ, Fritschen LJ, et al. (1989) Deep valley radiation and surface energy budget microclimates. Part II: Energy budget. J Appl Meteorol Climatol 28: 427-437. https://doi.org/10.1175/15200450(1989)028<0427:DVRASE > 2.0.CO;2

Yacono D (1968) The Ahaggar, Essay on Mountain Climate in the Sahara, Work of the Saharan Research Institute: 27, University of Algiers (In French)

Yoshino MM (1984) Thermal belt and cold air drainage on the mountain slope and cold air lake in the basin at quiet clear night. GeoJournal 8: 235-250. https://doi.org/10.1007/BFo0446473

Zeng Y, Qiu X, He Y, et al. (2009) Distributed modelling of monthly air temperatures over the rugged terrain of the Yellow River Basin. Sci China, D Earth Sci 52: 694-707. https://doi.org/10.1007/s11430-009-0059-2 